\title{
The Influence of Archaeometallurgical Copper Alloy Castings Microstructure towards Corrosion Evolution in Various Corrosive Media
}

\author{
Olga Papadopoulou *(D) and Panayota Vassiliou
}

Citation: Papadopoulou, O.; Vassiliou, P. The Influence of Archaeometallurgical Copper Alloy Castings Microstructure towards Corrosion Evolution in Various Corrosive Media. Corros. Mater. Degrad. 2021, 2, 227-247. https:// doi.org/10.3390/cmd2020013

Academic Editor: Guang-Ling Song

Received: 13 April 2021

Accepted: 14 May 2021

Published: 19 May 2021

Publisher's Note: MDPI stays neutral with regard to jurisdictional claims in published maps and institutional affiliations.

Copyright: (C) 2021 by the authors. Licensee MDPI, Basel, Switzerland. This article is an open access article distributed under the terms and conditions of the Creative Commons Attribution (CC BY) license (https:// creativecommons.org/licenses/by/ $4.0 /)$.
School of Chemical Engineering, National Technical University of Athens, 9 Iroon Polytechneiou str., 15780 Zografou, Greece; pvas@chemeng.ntua.gr

* Correspondence: olpap@central.ntua.gr

Abstract: The local patterns at the interfaces of corrosion stratification, developed on two archaeometallurgical bronzes (a Cu-Sn-Pb and a $\mathrm{Cu}-\mathrm{Zn}-\mathrm{Sn}-\mathrm{Pb}$ alloy), in the as-cast condition, were assessed by OM and SEM-EDS systematic elemental chemical analyses. Previously, the alloys-whose metallurgical features and electrochemical behaviour were already well studied-have been subjected to laboratory corrosion experiments. The corrosion procedures involved electrochemical anodic polarization experiments in various chloride media: $0.1 \mathrm{~mol} / \mathrm{L} \mathrm{NaCl}, 0.6 \mathrm{~mol} / \mathrm{L} \mathrm{NaCl}$ and two other synthetic chloride-containing solutions, representing electrolytes present in marine urban atmosphere and in the soil of coastal sites. The characterization of the $\mathrm{Cu}-\mathrm{Sn}-\mathrm{Pb}$ alloy electrochemical patinas after anodic sweep $(\mathrm{OCP}+0.6 \mathrm{~V})$ revealed that the metal in all electrolytes undergoes extensive chloride attack and selective dissolution of copper which initiates from the dendritic areas acting as anodic sites. The most abundant corrosion products identified by FTIR in all electrochemical patinas were $\left.\mathrm{Cu}_{2}(\mathrm{OH})_{3} \mathrm{Cl}\right), \mathrm{Cu}_{2}(\mathrm{OH})_{2} \mathrm{CO}_{3}$ and amorphous $\mathrm{Cu}$ and $\mathrm{Sn}$ oxides. The characterization of the $\mathrm{Cu}-\mathrm{Sn}$ $\mathrm{Pb}$ alloy electrochemical patina after slow anodic sweep $(\mathrm{OCP}+1.5 \mathrm{~V})$ in $0.1 \mathrm{~mol} / \mathrm{L} \mathrm{NaCl}$ reveals selective oxidation of dendrites and higher decuprification rate in these areas. Corrosion products of Sn-rich interdendritic areas are dominated by oxygen species (oxides, hydroxides, hydroxyoxides) and $\mathrm{Cu}$-rich dendrites by chlorides. In the case of $\mathrm{Cu}-\mathrm{Zn}-\mathrm{Sn}-\mathrm{Pb}, \mathrm{Zn}$ in dendritic areas is preferentially attacked. The alloy undergoes simultaneous dezincification and decuprification, with the former progressing faster, especially in dendritic areas. The two processes at the alloy/patina interface leave behind a metal surface where $\alpha$-dendrites are enriched in Sn compared to the alloy matrix. The results of this study highlight the dynamic profile of corrosion layer build-up in bronze and brass. Moreover, the perception of the dealloying mechanisms progression on casting features, at mid-term corrosion stages, is extended.

Keywords: archaeometallurgy; bronze; brass; microstructure; accelerated corrosion; chlorides; patina; decuprification; dezincification; FTIR spectroscopy

\section{Introduction}

Archaeometallurgical and historical bronzes and brasses are either cast or worked. In most cases, a combination of manufacturing and shaping techniques have been employed for their production. Therefore, the microstructural features of the final products are the result of alloying element concentration, presence of impurities, cooling rate and subsequent thermal or mechanical treatment [1]. Numerous modern archaeological and archaeometric studies have been dedicated to the investigation and reconstruction of manufacturing procedures and available bronze and brass metallurgical technology in many eras and geographical sites where ancient civilizations of the Old and New World have thrived [2]. A great number of the antiquity bronze artefacts, tools and coinage, and also historic and contemporary copper-based sculptures, are produced by casting. The 
corrosion phenomena on these unique categories of alloys inevitably take place on surfaces that, in some cases, are characterized by complex and heterogeneous topography.

During the last few decades, research on corrosion kinetics governing long-term exposure in various contexts-such as soil, marine and atmospheric environments (outdoor and indoor), etc. - has provided the field for important interdisciplinary studies [3-6]. Both case studies [7-11] and laboratory experiments [12-15] have investigated the composition of corrosion layer strata formed after long-term natural exposure and the role of numerous parameters affecting the electrochemical behaviour at the initial corrosion stages, respectively. The chemical composition and topography of the alloy substrate and the physicochemical properties of the corrosive medium are equally important for the assessment of corrosion process development and the nature of corrosion products. The well-established dealloying models in bronzes and brasses-i.e., decuprification [4] and dezincification [16] —are the necessary background for the interpretation of all types of degradation mechanisms in copper-based cultural heritage objects. The addition of tin as an alloying element in copper alloys can be responsible for either a positive or negative impact in corrosion rate, depending on the $\mathrm{pH}$ and the aggressive corrosive species concentration of the electrolyte, as well as the moisture levels that can promote the dissolution of water-soluble species.

The role of Sn corrosion products in (i) electrochemical reactions related to 'bronze disease' mechanism [17], (ii) redox reactions involved in deposition and dissolution processes among chloride-containing corrosion layers in unsheltered atmospheric conditions [18] and (iii) dezincification degree during long-term soil corrosion of ancient brass [19] has been the subject of recent studies. Two challenging intercorrelated research fields for corrosionists are the understanding of local galvanic cell action in dealloying processes and the assessment of local chemical reactions between distinct solid phases in the presence of aggressive corrosive agents. New emerging corrosion aspects and relevant physical models can facilitate a more accurate perception and validation of the corrosion kinetics of ancient bronze and brass in a wide range of corrosion environments.

Despite the progress and the increasing literature sources in the field of bronze and brass cultural heritage degradation and conservation, the experimental evidence focusing on the local corrosion patterns related to micro-segregation structures-present in archaeometallurgical castings-is rather limited [17,20-23]. Masi et al. [22] have investigated the corrosion patterns related to the dendritic microstructures of as-cast historical bronzes. Characterization of patinas, after artificial ageing tests simulating atmospheric corrosion, has pointed out the emergence of local galvanic cells due to different alloy phase chemical composition. Dendrite cores- $\alpha$-phase with the lowest $S n$ content-act as anodic sites, while interdendritic areas-eutectoid phase and $\delta$-phase- act as local cathodes and are corroded to a lesser extent. Apart from the degree of electrochemical attack, the nature of corrosion products also varies between the dendrite core and external boundaries, and even more so between dendrite structures and interdendritic areas [22,23].

Filling the gap of knowledge between the early stages of electrochemical corrosion and the complex stratification after long-term corrosion phenomena in cultural heritage metals is an on-going field of research, and many questions still remain to be answered. The aim of this work is to contribute to the establishment of a universal framework for the interpretation of localized corrosion phenomena in segregated archaeometallurgical copper-based castings, with particular interest in the deeper understanding of severe electrochemical dissolution and chemical leaching mechanisms in various corrosive media. The study of the localized corrosion patterns encountered in archaeological and historical metals is also of great importance and would allow the design of suitable cleaning procedures and protection systems that would not affect or destroy the original metallurgical microstructure or the corrosion stratification. This information is valuable in archaeometric studies and should be treated as part of the archaeological record of cultural heritage metals. Two reference archaeometallurgical copper alloys-representing a typical ternary bronze whose production can be traced from Early Bronze Age in many locations of the Mediterranean and a quaternary brass of the Roman Period-were originally produced for 
the purposes of the EFESTUS project [24]. The two castings were used for electrochemical potentiodynamic tests in various synthetic solutions representing the chloride-containing electrolytes involved in marine, soil or atmospheric corrosion processes. The local corrosion patterns of the produced electrochemical patinas-related to dendritic segregation of the reference cast alloys-were studied by combined microscopic and analytical methods. A comprehensive demonstration of the alloying elements and corrosive species distribution across the corrosion stratification as a result of accelerated dealloying is attempted.

\section{Materials and Methods}

Specimens of two reference copper alloys, a Tin-bronze (TB): $92.3 \mathrm{Cu}, 7.5 \mathrm{Sn}$ and $0.2 \mathrm{~Pb}$ and a Zinc-bronze (ZB): $82.5 \mathrm{Cu}, 14.0 \mathrm{Zn}, 3.0 \mathrm{Sn}$ and $0.5 \mathrm{~Pb}$ (\% weight composition), produced by a casting technique similar to ancient metallurgy practices [25], were used for laboratory corrosion tests. The bronze specimens were cut from rod castings (cylinder disks of $26 \mathrm{~mm}$ diameter and $3 \mathrm{~mm}$ thickness) and were used in the as-cast condition without further metallurgical treatment. As a result, the alloy surfaces are highly inhomogeneous when examined from the center towards the disc edge and maintain all the typical characteristics of castings before annealing: dendritic microstructure and defects, such as pores and impurities. The bronze coupons were soldered on metallic bases and then mounted in epoxy resin in order to manufacture reusable working electrodes for the electrochemical tests. Before each potentiodynamic sweep, the electrode surface was ground from 400 up to 1500 grit; afterwards they were rinsed with deionised water, degreased with ethanol and finally dried in an air stream.

Before the corrosion experiments, metallographic studies on the alloy surfaces was performed by colour etching with Klemm II reagent [26], after suitable grinding and polishing procedures. Macro-photographic documentation and metallographic observations were conducted by optical microscopy (OM) using a Leitz Aristomet metallographic microscope.

Four aqueous solutions-representing chloride-containing electrolytes available at wet conditions in various corrosion environments of the Mediterranean basin (such as seawater, soil, atmosphere)-were employed in accelerated electrochemical corrosion: 0.1 and $0.6 \mathrm{~mol} / \mathrm{L} \mathrm{NaCl}$ (average seawater salinity in Mediterranean basin), a filtrate extracted by Piraeus soil (PRSF) and a aqueous mixture of typical atmospheric pollutants in the city of Athens (AAPM), which can be regarded as an industrial-marine atmospheric environment.

The PRSF electrolyte was produced by adding $100 \mathrm{~g}$ soil to $400 \mathrm{~mL}$ deionised water, heating at $60-70{ }^{\circ} \mathrm{C}$ for $30 \mathrm{~min}$ under vigorous stirring and by subsequent filtration and dilution to a final volume of $500 \mathrm{~mL}$. The soil was collected from an excavation site near the Archaeological Museum of Piraeus, where many archaeological bronze objects have been recovered during the last few decades. The chemical composition has been analysed according to ISO11464 method (Table 1).

Table 1. Piraeus soil analysis according to ISO11464.

\begin{tabular}{ccccccc}
\hline $\begin{array}{c}\mathrm{Cl}^{-} \\
(\mathbf{m g} / \mathbf{g})\end{array}$ & $\begin{array}{c}\mathrm{SO}_{4}{ }^{2-} \\
(\mathbf{m g} / \mathbf{g})\end{array}$ & $\begin{array}{c}\mathrm{HCO}_{3}{ }^{-} \\
(\mathbf{m g} / \mathbf{g})\end{array}$ & $\begin{array}{c}\mathrm{TOC} \\
(\mathbf{m g} / \mathbf{g})\end{array}$ & $\begin{array}{c}\mathrm{Mg} \\
(\mathbf{m g} / \mathbf{g})\end{array}$ & $\begin{array}{c}\mathrm{Fe} \\
(\mathbf{m g} / \mathbf{g})\end{array}$ & $\begin{array}{c}\mathrm{Ca} \\
(\mathbf{m g} / \mathrm{g})\end{array}$ \\
\hline 11.5 & 25.0 & 0.5 & 1.2 & 32.0 & 4.9 & 98.0 \\
\hline
\end{tabular}

The AAPM electrolyte, of a total salt concentration $0.97 \% w / v$, contains the following ionic species: sulphates, nitrates, chlorides and carbonates. The synthesis of the aqueous solution was based on reported data concerning the detected atmospheric aerosol and gaseous pollutants in Athens city during the 1990s [27]. It can be assumed that it approximates the chemical composition of a precipitated electrolyte film that could form on bronze sculpture exposed in unsheltered outdoor conditions. The particular electrolyte must be regarded as less corrosive than acid rain. The molar concentration of all ionic species is given in Table 2. 
Table 2. Molar concentrations of the ionic species in the synthesised AAPM electrolyte.

\begin{tabular}{cccc}
\hline $\mathrm{SO}_{4}{ }^{2-}(\mathrm{mol} / \mathrm{L})$ & $\mathrm{NO}_{3}{ }^{-}(\mathrm{mol} / \mathrm{L})$ & $\mathrm{Cl}^{-}(\mathbf{m o l} / \mathrm{L})$ & $\mathrm{HCO}_{3}{ }^{-}(\mathrm{mol} / \mathrm{L})$ \\
\hline 0.050 & 0.025 & 0.008 & $5 \cdot 10^{-5}$ \\
\hline
\end{tabular}

A GAMRY CMS 100 potentiostat and software connected to a three-electrode cell was employed for the electrochemical potentiodynamic tests. The archaeometallurgical coupon was the static working electrode (WE), a saturated calomel electrode (SCE) was used as reference and a $\mathrm{Pt}$ wire was used as a counter electrode. The active surface area of the WE was $5 \mathrm{~cm}^{2}$. Anodic polarization sweeps $(\mathrm{OCP}+0.6 \mathrm{~V})$ at a scan rate of $1 \mathrm{mV} / \mathrm{s}$ were performed in $0.6 \mathrm{~mol} / \mathrm{L} \mathrm{NaCl}$, PRSF and AAPM, using TB reference electrodes in an electrochemical cell of $500 \mathrm{~mL}$ volume. Broader anodic polarization sweeps $(\mathrm{OCP}+1.5 \mathrm{~V})$ at a very slow scan rate of $0.25 \mathrm{mV} / \mathrm{s}$ were conducted in $0.1 \mathrm{~mol} / \mathrm{L} \mathrm{NaCl}$, using TB and $\mathrm{ZB}$ in an electrochemical cell of $2 \mathrm{~L}$. The two scan rates for the anodic polarization were selected in order to achieve two different dealloying conditions that would represent slow and accelerated dissolution. The very slow scan rate of $0.25 \mathrm{mV} / \mathrm{s}$ better approaches the progression of natural electrochemical actions and leaching in dense electrolytes, where mass transport takes control over charge transfer. The fast scan rate $(1 \mathrm{mV} / \mathrm{s})$ is a typical rate used in most of the wet electrochemistry potentiodynamic techniques aimed at corrosion rate determination.

The electrochemical potentiodynamic curves of TB in $0.6 \mathrm{~mol} / \mathrm{L} \mathrm{NaCl}$ and in PRSF and AAPM electrolytes, as well as those of $\mathrm{ZB}$ in $0.1 \mathrm{~mol} / \mathrm{L} \mathrm{NaCl}$, have been presented in previous works $[28,29]$, where all the details about the electrochemical experiments methodology, setup and the resulting electrochemical behaviour of the alloys are discussed. In this work, the authors continue the results evaluation with a systematic ex situ characterization of all patinas. Scanning Electron Microscopy (SEM) coupled with Energy Dispersive Spectrometry (EDS) was employed for the morphological and elemental chemical analysis, using a FEI Quanta 200 scanning electron microscope equipped with a tungsten filament coupled with an EDAX analyser. The accelerating voltage of the incident electron beam was set to $20 \mathrm{kV}$. OM observations of the corroded surfaces, under polarized light, were carried out in order to study the corroded electrode surface after each test.

- $\quad(\mathrm{OCP}+0.6 \mathrm{~V}$, scan rate $1 \mathrm{mV} / \mathrm{s})$ : $\mathrm{OM}$ observations on the corroded electrode surfaces were conducted in some representative areas of TB electrochemical patinas. Patina fragments were collected from all three electrodes to perform morphological examination by SEM and chemical analyses by FTIR and EDS. Patina fractions were detached using a carbon adhesive tape to examine both internal and external surfaces by SEMEDS. The EDS data (elemental analyses) were processed to serve the investigation of the alloy/patina and patina/electrolyte interface reactions. Similar analyses were also conducted on the metal substrate (areas under detached patinas). Finally, powder micro-samples were mechanically scraped from the three corroded electrode surfaces and were homogenized in order to produce $\mathrm{KBr}$ pellets. The FTIR measurements were conducted by an JASCO FT/IR-4200 spectrometer (JASCO International Co. Ltd., Tokyo, Japan) with a TGS detector. All spectra were recorded at a scan range of $4000-400 \mathrm{~cm}^{-1}$, with accumulation set to 32 and resolution to $4.0 \mathrm{~cm}^{-1}$, and underwent baseline correction, smoothing and $\mathrm{CO}_{2}$ peak reduction through Spectra Manager software.

- $(\mathrm{OCP}+1.5 \mathrm{~V}$, scan rate $0.25 \mathrm{mV} / \mathrm{s})$ : The same methodology was applied for the characterization of TB and ZB electrochemical patinas after the end of anodic polarization sweeps in $0.1 \mathrm{~mol} / \mathrm{L} \mathrm{NaCl}$. These systematic chemical and morphological analyses were employed in order to study the elemental distribution as a result of the alloy dissolution and the precipitation of corrosion compounds at the metal/patina and patina/electrolyte interfaces. In the case of ZB patina, a brief characterization of corrosion patterns by OM and SEM-EDS has been published by the authors in a previous 
work [29], together with time-lapse photographic documentation of the electrochemical reactions during the sweep and comments on the electrochemical curves.

\section{Results}

\subsection{Metallographic Characterization of Reference Archaeometallurgical Alloys}

Colour etching with Klemm II reagent revealed the microstructure of the as-cast electrodes. The surfaces macro-photographic documentation reveals the macro-segregation features. A great variation of the grain size and shape distribution along the electrode disc radius is observed, as a result of the ingot cooling process. These characteristics are demonstrated in Figure 1 for the ZB alloy. Small-sized grains (skin area) are the first to solidify as a result of the contact of the melt with the mould. Moving towards the centre, the growth of columnar grains (basaltic zone) is observed, and at the ingot centre a cluster of equiaxed grains is the last to solidify. Inside the grains, the dendritic segregation is clearly depicted (Figure 1b), especially for the ZB alloy, where the dendrites are larger and well-shaped.

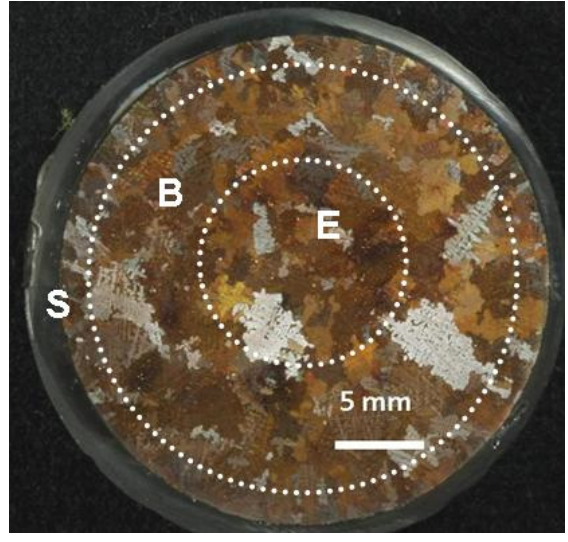

(a)

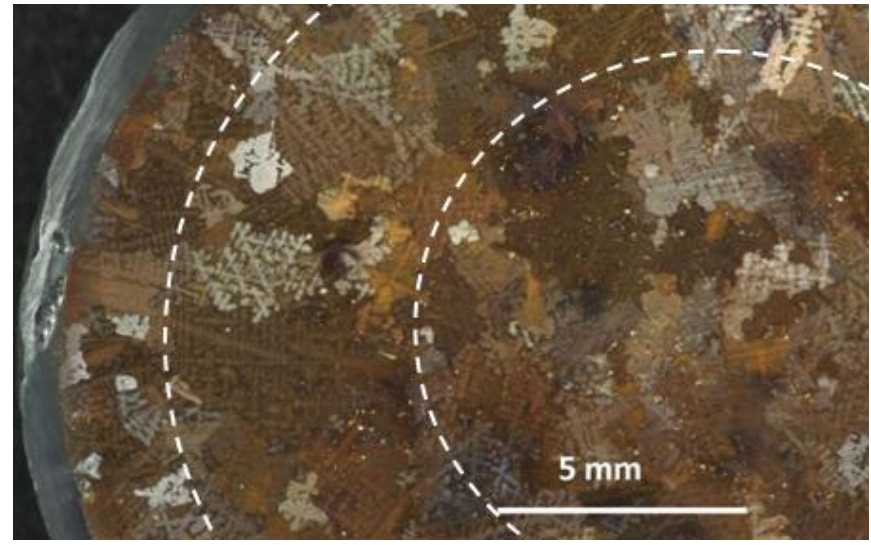

(b)

Figure 1. Macro-photographic documentation of ZB reference alloy after colour etching with Klemm II reagent: (a) the whole specimen surface; (b) detail of previous depicting the dendritic structure inside the grains. The dotted lines highlight the boundaries between the distinct zones of the solidification process (where S: skin, B: basaltic area and E: equiaxed grains area).

According to the nominal composition of the archaeometallurgical alloys and the phase diagrams [1] corresponding to non-equilibrium conditions that apply for usual casting procedures, three phases are present in the TB alloy-an $\alpha-(\mathrm{Cu}-\mathrm{Sn})$ dendritic network, an $(\alpha+\delta)$-eutectoid phase and an immiscible $\mathrm{Pb}$ phase-and two phases in the $\mathrm{ZB}$ alloy-an $\alpha-(\mathrm{Cu}-\mathrm{Zn}-\mathrm{Sn})$ phase and an immiscible $\mathrm{Pb}$ phase. Optical microscope images from the etched surfaces, indicative of the micro-segregation features, are presented in Figure 2. TB exhibits a cored dendritic structure (Figure 2a). The Cu-depletion gradient of alpha dendrites is visible by the colour variation from dark brown in the centre of the alpha dendrites to pink borders. The dendrites have rounded branches and irregular shape.

The interdendritic area corresponds to $\alpha+\delta$ eutectoid solid solution, which is visible in dark red with silver-grey islets of $\delta$ phase $\left(\mathrm{Cu}_{31} \mathrm{Sn}_{8}\right)$. The grain boundaries of this alloy are not easily distinguished. Usually, the Sn-rich $\delta$ phase tends to precipitate between the grains (Figure 2a), because it solidifies at a lower temperature. ZB also exhibits a dendritic segregation, but no coring was evidenced. The grain boundaries of large grains are visible after etching along with porosity and inclusions related to the casting process (Figure 2b). 


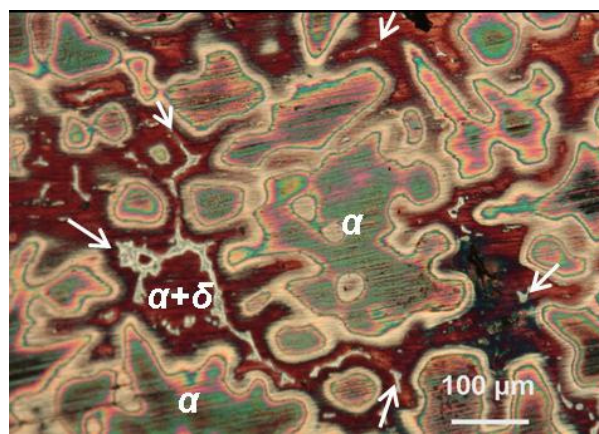

(a)

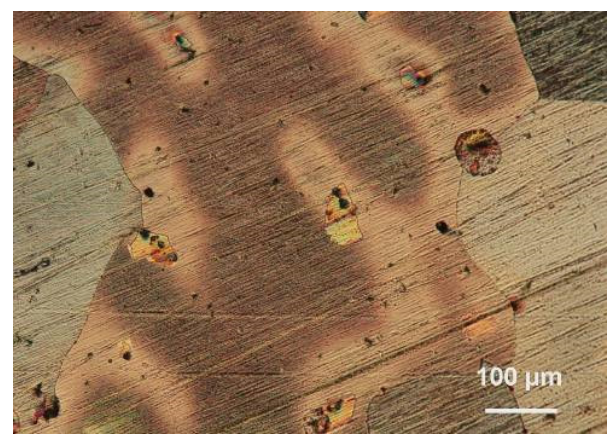

(b)

Figure 2. Optical microscope images $(\times 100)$ of: (a) TB (the arrows indicate the islets of $\delta$ phase inside the $\alpha+\delta$ eutectoid); (b) ZB archaeometallurgical alloy after colour etching by Klemm II reagent, revealing the dendritic microstructure of the as-cast surfaces.

\subsection{Accelerated Corrosion in Total Immersion Conditions/Anodic Polarization in Various Electrolytes}

3.2.1. 1st Experimental Section-Characterization of Electrochemical Patinas in Three Synthetic Electrolytes

The electrochemical behaviour of TB casting in three solutions representing the electrolytes available in different marine environments (urban atmosphere near coast, soil in coastal site, seawater) and the most representative corrosion features of the distinct solidification zones, created by macro-segregation, have been reported in [28]. In all corrosive media, the corrosion attack starts from the electrode disc edge and proceeds towards its centre, following the direction of the solidification front. More specifically, EDS elemental analyses on TB corroded surface after anodic dissolution in $0.6 \mathrm{~mol} / \mathrm{L} \mathrm{NaCl}$ has pointed out higher tin and oxygen levels near the electrode edge compared to the electrode centre. This finding indicates a faster progress of copper dissolution at the periphery. In this work, the investigation continues further with validation of these findings by more elaborate chemical characterization of electrochemical patinas and with studies on micro-segregation influence in corrosion evolution. The anodic polarization curves in $0.6 \mathrm{~mol} / \mathrm{L} \mathrm{NaCl}, \mathrm{PRSF}$ and AAPM electrolytes [28] are presented again in Figure 3 to give an overview of the corrosion systems and to facilitate discussion.

TB Anodic Polarization (OCP + 0.6V / Scan RAte :1 mV/s)

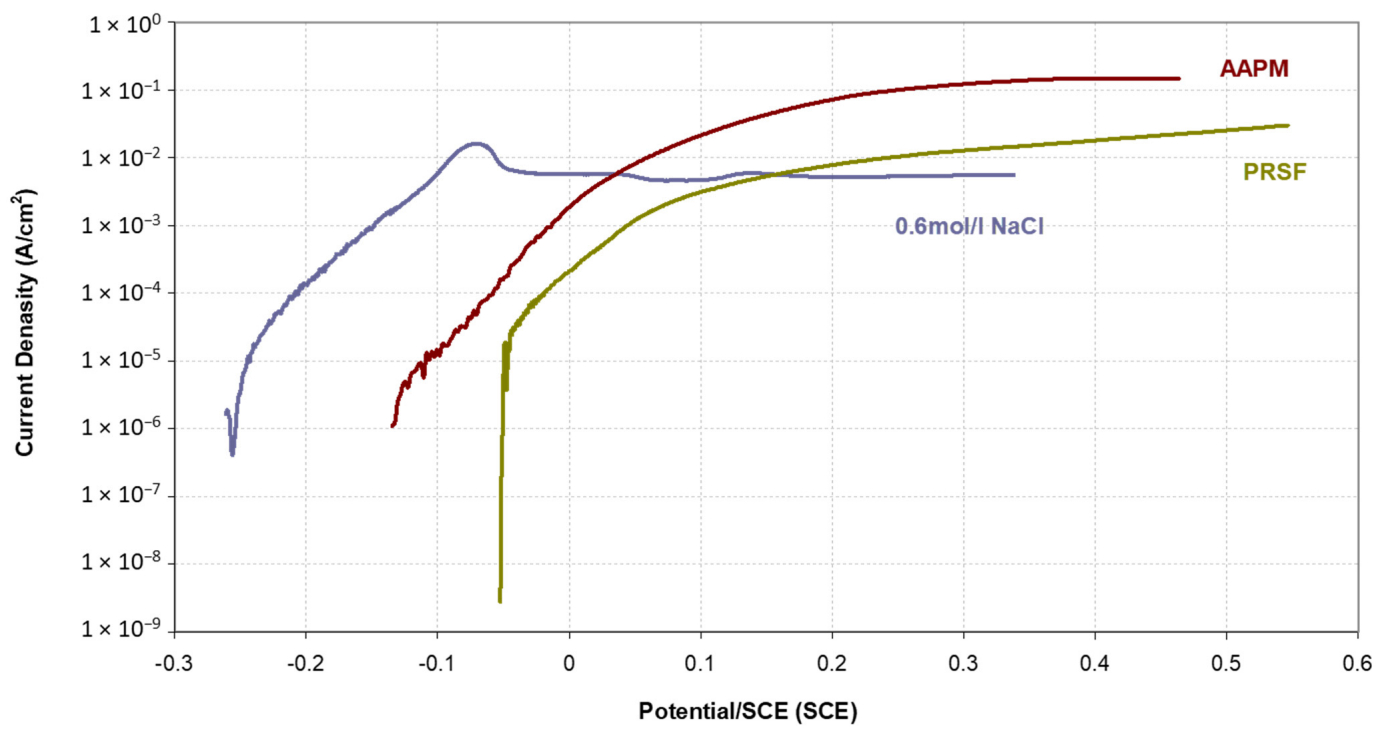

Figure 3. Anodic polarization curves $(\mathrm{OCP}+0.6 \mathrm{~V})$ acquired in the three corrosive media at a typical scan rate of $1 \mathrm{mV} / \mathrm{s}$, after $1 \mathrm{~h}$ at OCP conditions. Data first presented in [28]. 
$\mathrm{OM}$ images of electrochemical patina grown on a TB- $0.6 \mathrm{~mol} / \mathrm{L} \mathrm{NaCl}$ system are presented in Figures 4 and 5. The local patterns from electrode edge (Figure 4) and centre (Figure 5) reveal a variety of precipitated dissolution products which follow the cored dendritic structure of the alloy substrate.

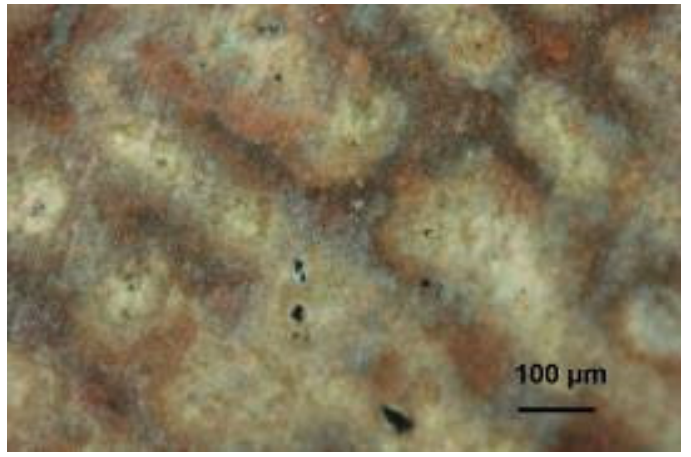

(a)

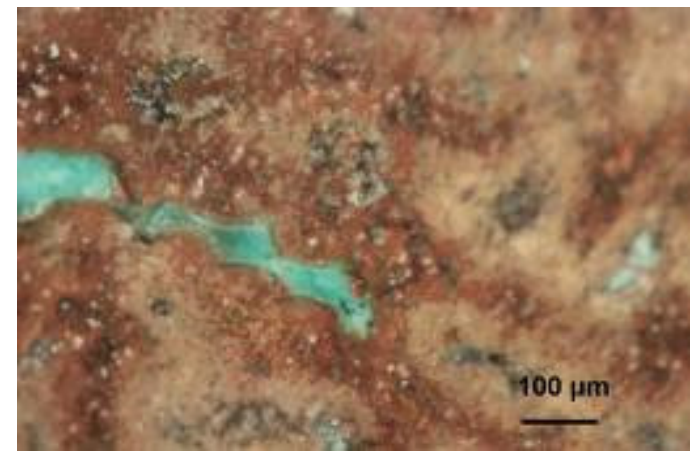

(b)

Figure 4. OM images $(\times 100)$ of the corrosion patterns observed at the segregated surface of TB castings after the end of anodic sweeps in $0.6 \mathrm{~mol} / \mathrm{L} \mathrm{NaCl}$ : (a) corroded dendritic structure and (b) $\mathrm{Cu}$ (II) corrosion products formation inside voids -These features are encountered near the electrode edge.

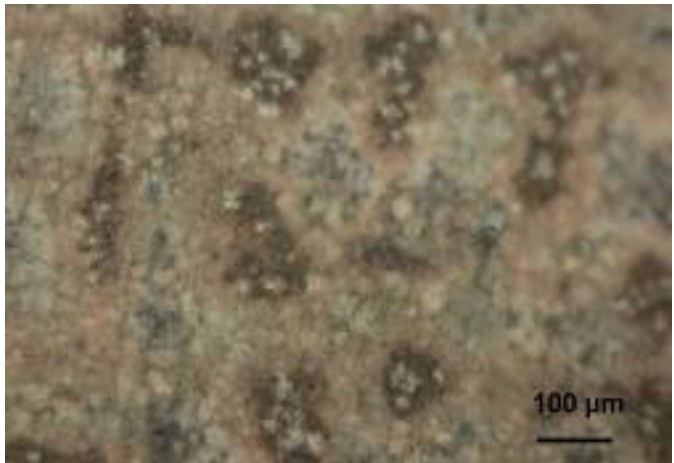

(a)

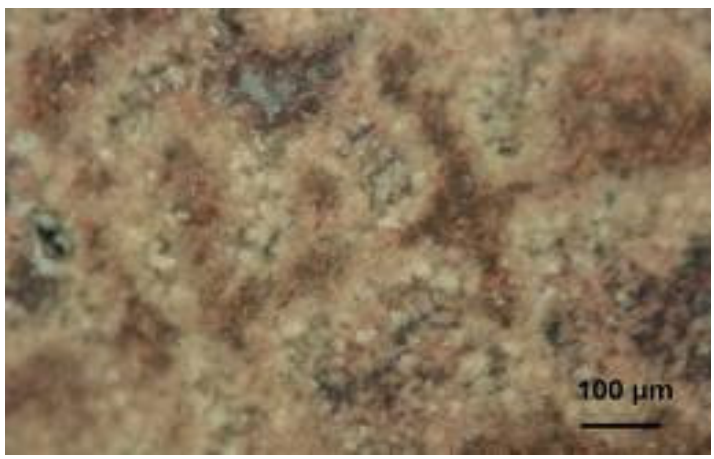

(b)

Figure 5. OM pictures $(\times 100)$ of the corrosion patterns observed at the segregated surface of TB castings after the end of anodic sweeps in $0.6 \mathrm{~mol} / \mathrm{L} \mathrm{NaCl}$ : (a) and (b) corresponding to two different areas where the cored dendritic structure exhibits local dealloying patterns - These features are encountered near the electrode centre.

The centres of dendrites bodies and branches correspond to the metallic $\mathrm{Cu}$ or oxidized $\mathrm{Cu}(\mathrm{I})$ state, while dendrite boundaries (shown in pink colour) are a mixture of $\mathrm{Cu}(\mathrm{I})$ and Sn(IV) compounds. The interdendritic areas are covered by white Sn(IV) compounds, which contribute to the stabilization behaviour of the alloy at high anodic potentials. In Figure $4 \mathrm{~b}$, the evolution of green $\mathrm{Cu}(\mathrm{II})$ hydroxyl-chlorides inside the voids is observed.

The relevant OM images from the corroded TB surfaces in PRSF and AAPM electrolytes were dominated by light green powdery $\mathrm{Cu}$ (II) compounds. A thicker deposition of these compounds was observed on the $\alpha$-dendrite network in PRSF while, in the case of AAPM, the green electrochemical patina was uniform [28]. The corrosion patterns on the internal surface (interface with alloy) of the two latter patinas are depicted by SEM in Figure 6. 


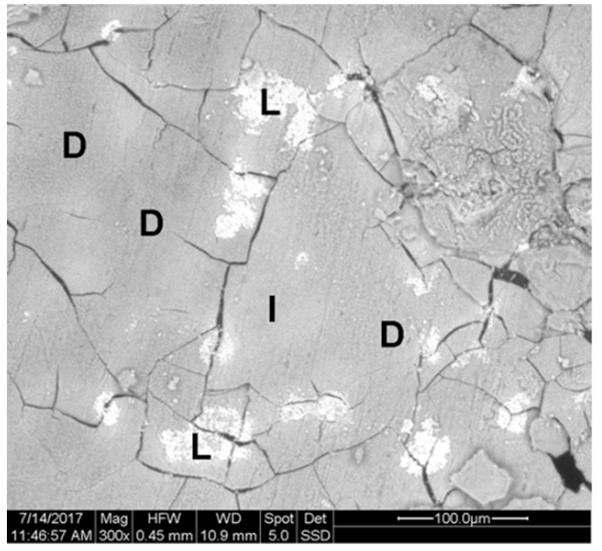

(a)

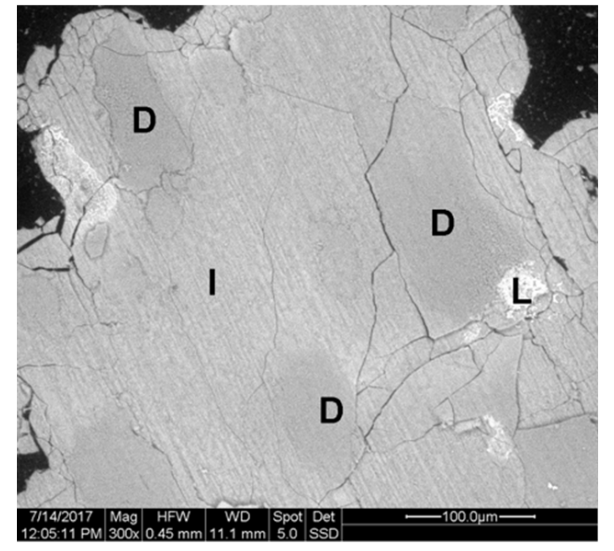

(b)

Figure 6. SEM backscattered electron images $(\times 300)$ of TB electrochemical patinas samples (internal surface in contact with metal substrate) formed after anodic polarization (OCP+ 0.6 V) in (a) AAPM and (b) PRSF electrolyte (D: dendrite, I: interdendritic area, L: lead islet).

The chemical characterization of AAPM-produced electrochemical patina is discussed in detail. EDS data from the distinct dendritic, interdendritic areas and lead globules were processed to assess the alloying elements and corrosive species distribution (Table 3). The corrosion products that evolved on dendrites contain higher $\mathrm{Cu}$ concentration compared to the interdendritic areas, in accordance with the micro-segregation terrain of the bronze substrate. The general trend of $\mathrm{Cu}$ and $\mathrm{Sn}$ alloying elements distribution in the corroded micro-segregated structures of TB casting after the anodic sweep in AAPM are in accordance with the corroded structures found in a quaternary $\mathrm{Cu}-\mathrm{Sn}-\mathrm{Zn}-\mathrm{Pb}$ alloy casting after artificial ageing tests (dropping test, wet and dry cycles) with artificial rain solution [23], which also contains sulphates, chlorides and nitrate species. However, both patina areas are Sn-enriched in respect to the metal matrix atomic concentration ( $4 \%$ at Sn). The dendrite corrosion features exhibit an average $13 \%$ Sn content, and the interdendritic ones exhibit $16 \% \mathrm{Sn}$. The lead-rich corrosion islets have an average $20 \% \mathrm{~Pb}$ and $18 \% \mathrm{Sn}$.

Table 3. Normalized \% atomic elemental distribution of $\mathrm{O}, \mathrm{Cl}, \mathrm{S}$ and $\mathrm{N}$ (corresponding to $\mathrm{O}^{2-}, \mathrm{Cl}^{-}$, $\mathrm{SO}_{4}{ }^{2-}$ and $\mathrm{NO}_{3}{ }^{-}$anionic species), detected by EDS on the internal surface of TB electrochemical patina, produced by anodic polarization in AAPM. Average values of indicative spot analyses conducted in dendritic, interdendritic areas and $\mathrm{Pb}$ islets.

\begin{tabular}{cccc}
\hline Element & Dendritic Network & Interdendritic Areas & Leaded Areas \\
\hline $\mathrm{O}$ & 76.0 & 71.5 & 73.2 \\
$\mathrm{Cl}$ & 22.8 & 27.0 & 14.0 \\
$\mathrm{~S}$ & 1.2 & 1.5 & 8.0 \\
$\mathrm{~N}$ & - & - & 4.8 \\
\hline
\end{tabular}

The identification of the majority of patina constituents (from all corrosion strata and not just the superficial layer) was possible by spectroscopic analyses on pulverized and homogenized corrosion depositions. Here, the vibrational patterns of the FTIR spectra of all three electrochemical produced patinas are presented (Figure 7). 


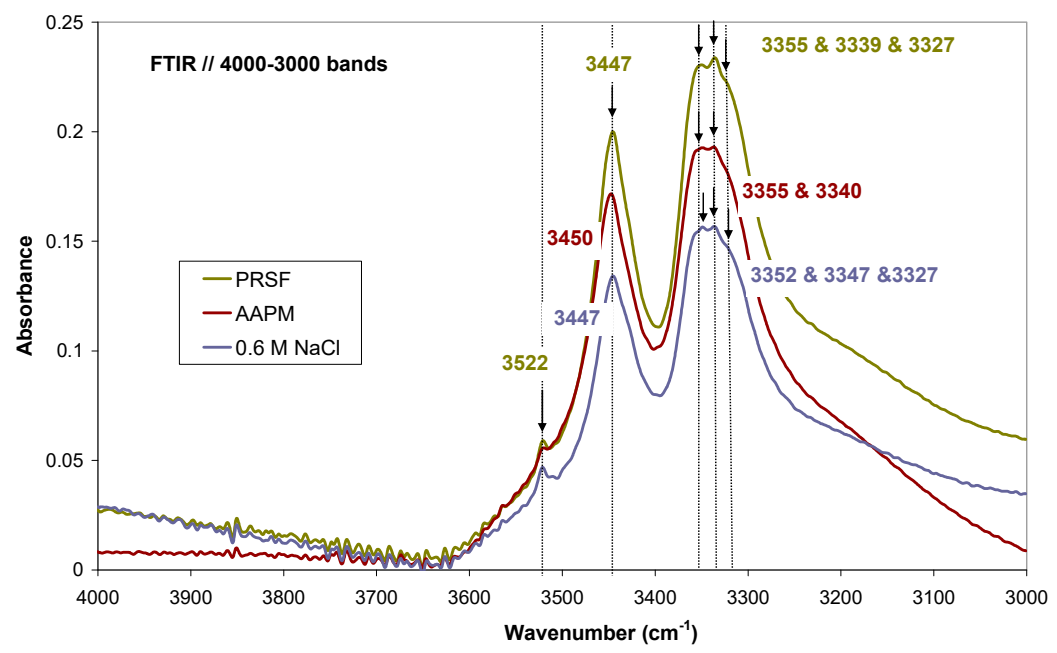

(a)

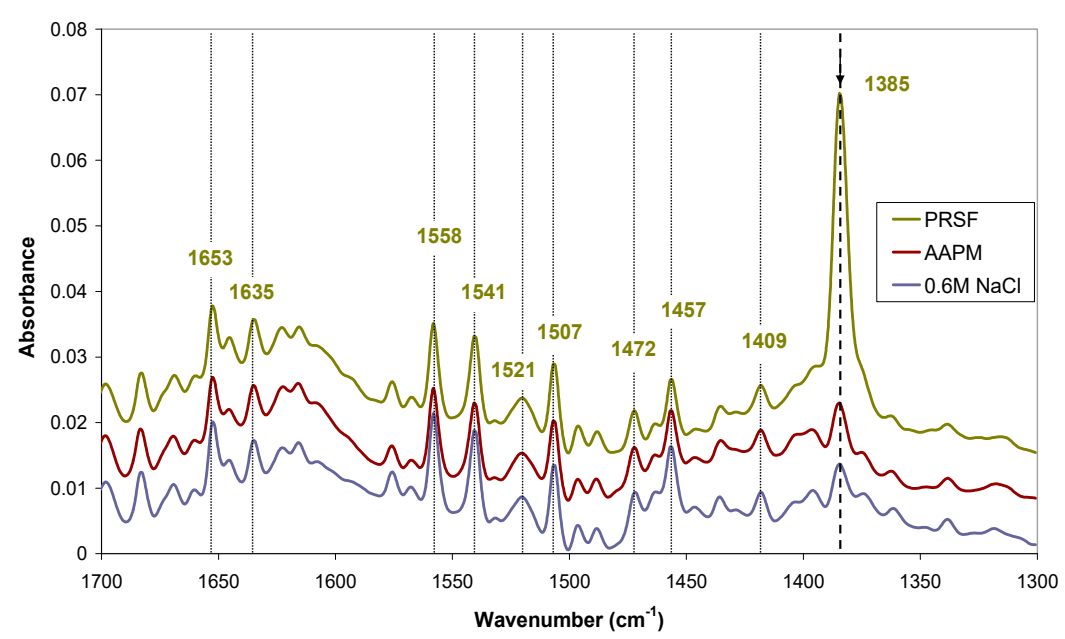

(b)

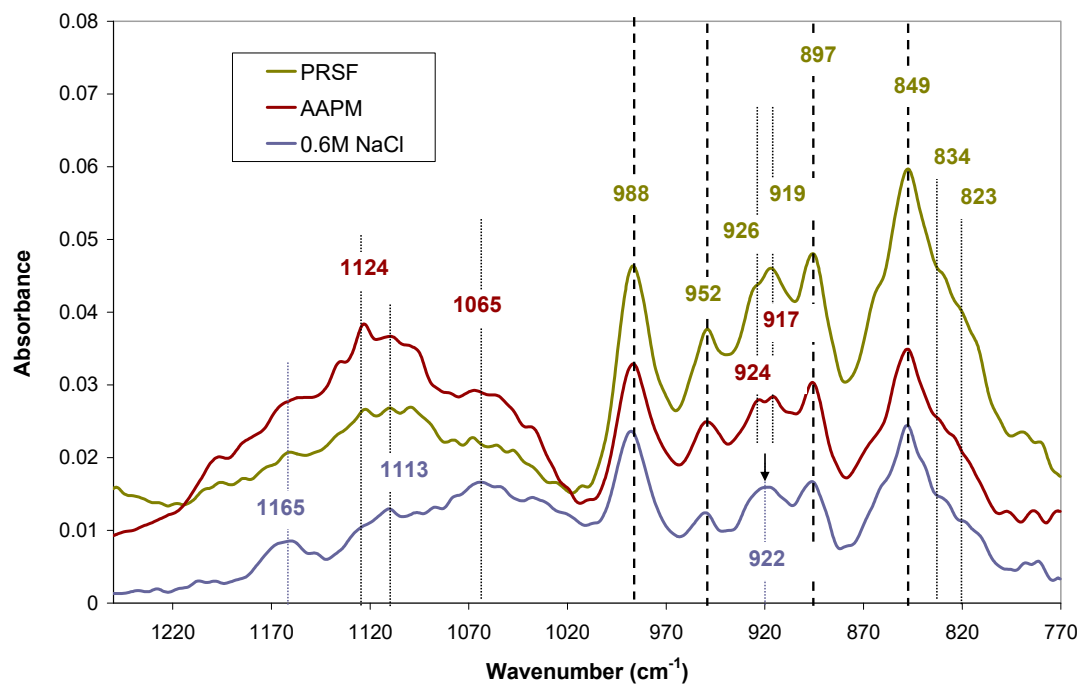

(c)

Figure 7. Cont. 


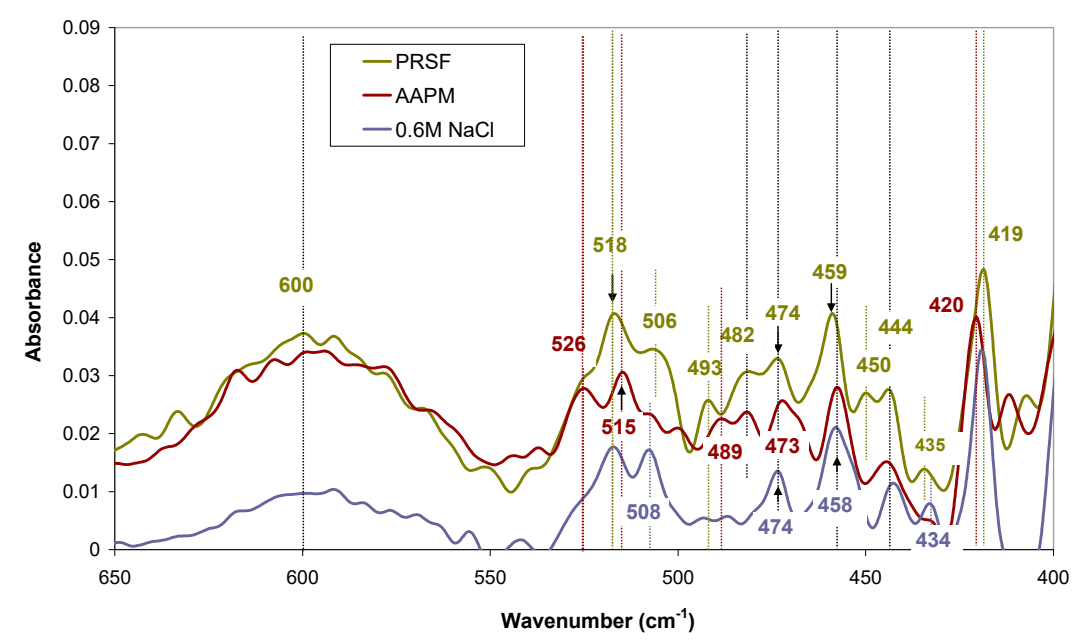

(d)

Figure 7. FTIR spectra of corrosion products collected from TB electrode surfaces at the end of anodic sweeps $(\mathrm{OCP}+0.6 \mathrm{~V})$ in $0.6 \mathrm{~mol} / \mathrm{L} \mathrm{NaCl}, \mathrm{AAPM}$ and PRSF electrolytes: (a) Bands $4000-3000 \mathrm{~cm}^{-1}$, (b) bands $1700-1300 \mathrm{~cm}^{-1}$, (c) bands $1270-770 \mathrm{~cm}^{-1}$ and (d) bands $650-400 \mathrm{~cm}^{-1}$.

The two powder samples (AAPM and PRSF patinas) were light green, and the third $(0.6 \mathrm{M} \mathrm{NaCl}$ patina) was whitish. The most important vibrational patterns are summarized in Table 4.

Table 4. Observed bands in FTIR spectra of homogenized patina powder samples after anodic polarization in PRSF, AAPM and $0.6 \mathrm{~mol} / \mathrm{L} \mathrm{NaCl}$.

\begin{tabular}{|c|c|c|c|c|}
\hline Corrosive Medium & Type of Vibration & Bands $\left(\mathrm{cm}^{-1}\right)$ & Attribution & Reference \\
\hline PRSF & \multirow{3}{*}{$\mathrm{OH}$ stretching } & $\begin{array}{c}3522(\mathrm{w}), 3447(\mathrm{~s}), 3355,3339 \\
3327 \text { (triple broad peak) }\end{array}$ & \multirow{3}{*}{$\begin{array}{c}\mathrm{Cu}_{2}(\mathrm{OH})_{3} \mathrm{Cl} \text {-intermediate of } \\
\text { botallackite and } \\
\text { atacamite polymorphs }\end{array}$} & \multirow{3}{*}{ [30-32] } \\
\hline AAPM & & $\begin{array}{c}3522(\mathrm{w}), 3450(\mathrm{~s}), 3355,3340 \\
\text { (triple broad peak) }\end{array}$ & & \\
\hline $0.6 \mathrm{~mol} / \mathrm{L} \mathrm{NaCl}$ & & $\begin{array}{c}3522(\mathrm{w}), 3447(\mathrm{~s}), 3352,3347 \\
3327 \text { (triple broad peak) }\end{array}$ & & \\
\hline all electrolytes & $\begin{array}{l}\text { in-plane } \mathrm{OH} \text { deformation } \\
\text { of } \mathrm{H}_{2} \mathrm{O}\end{array}$ & $\begin{array}{c}\text { many weak bands } \\
\text { within } 1620-1660 \\
\text { range }\end{array}$ & Sn oxyhydroxides & [33] \\
\hline all electrolytes & $\begin{array}{l}\text { weak overtones of Sn-O-Sn } \\
\text { and Sn-O-H }\end{array}$ & $\begin{array}{c}1558,1541,1521,1507,1472 \\
1457,1409\end{array}$ & Sn oxyhydroxides & [34] \\
\hline PRSF & & 1385 (strong) & \multirow{3}{*}{$\mathrm{Cu}_{2}(\mathrm{OH})_{2} \mathrm{CO}_{3}$-malachite } & \multirow{3}{*}[35,36]{} \\
\hline AAPM & & 1385 (weak) & & \\
\hline $0.6 \mathrm{~mol} / \mathrm{L} \mathrm{NaCl}$ & & 1385 (weak) & & \\
\hline AAPM & internal vibration of $\mathrm{SO}_{4}{ }^{2-}$ & 1124 & $\begin{array}{l}\mathrm{Cu}_{4}(\mathrm{OH})_{6} \mathrm{SO}_{4} \text {-brochantite or } \\
\text { posnjakite or Sn oxyhydroxides }\end{array}$ & \multirow{2}{*}[34,35]{} \\
\hline $0.6 \mathrm{~mol} / \mathrm{L} \mathrm{NaCl}$ & $\begin{array}{l}\text { weak overtones of Sn-O-Sn } \\
\text { and Sn-O-H }\end{array}$ & 1113 & Sn oxyhydroxides & \\
\hline PRSF & \multirow{4}{*}{$\mathrm{OH}$ deformation } & $988,952,926,919,897,849$ & $\mathrm{Cu}_{2}(\mathrm{OH})_{3} \mathrm{Cl}$-atacamite & {$[30-32,35]$} \\
\hline AAPM & & $988 *, 952,924,917,897,849$ & $\begin{array}{c}\mathrm{Cu}_{2}(\mathrm{OH})_{3} \mathrm{Cl} \text {-atacamite } \\
\text { * also } \mathrm{Cu}_{4}(\mathrm{OH})_{6} \mathrm{SO}_{4} \text { - brochantite } \\
\text { (Cu-OH bending) }\end{array}$ & {$[30-32,35]$} \\
\hline $0.6 \mathrm{~mol} / \mathrm{L} \mathrm{NaCl}$ & & $988,952,922,897$ & $\mathrm{Cu}_{2}(\mathrm{OH})_{3} \mathrm{Cl}$-atacamite & [30-32] \\
\hline All electrolytes & & 834 (sh), 823 (sh) & $\mathrm{Cu}_{2}(\mathrm{OH})_{2} \mathrm{CO}_{3}$-malachite & {$[35]$} \\
\hline all electrolytes & $\mathrm{Sn}-\mathrm{O}$ or $\mathrm{Cu}-\mathrm{O}$ vibrations & 600 (broad) & $\begin{array}{l}\text { nanocrystalline or amorphous } \mathrm{SnO}_{2} \\
\text { or } \mathrm{Cu}_{2} \mathrm{O}\end{array}$ & [36] \\
\hline
\end{tabular}


Table 4. Cont.

\begin{tabular}{|c|c|c|c|c|}
\hline Corrosive Medium & Type of Vibration & Bands $\left(\mathrm{cm}^{-1}\right)$ & Attribution & Reference \\
\hline PRSF & \multirow{3}{*}{$\mathrm{Cu}-\mathrm{O}$ and $\mathrm{Cu}-\mathrm{OH}$} & 526 (sh), 518, 506 & \multirow{3}{*}{$\begin{array}{l}\text { intermediate of atacamite and } \\
\text { botallackite, malachite }\end{array}$} & \multirow{3}{*}[31,35]{} \\
\hline AAPM & & $526,515,508$ & & \\
\hline $0.6 \mathrm{~mol} / \mathrm{L} \mathrm{NaCl}$ & & $526(\mathrm{sh}), 518,508$ & & \\
\hline PRSF & \multirow{2}{*}{$\mathrm{Cu}-\mathrm{O}$ stretching } & 492,482 & \multirow{2}{*}{$\begin{array}{c}\mathrm{Cu}_{2.5}(\mathrm{OH})_{2} \mathrm{CO}_{3}-\text { malachite and } \\
\mathrm{Cu}_{4}(\mathrm{OH})_{6} \mathrm{SO}_{4} \text { - brochantite }\end{array}$} & \multirow{2}{*}{ [35] } \\
\hline AAPM & & 489,482 & & \\
\hline PRSF & \multirow{3}{*}{$\mathrm{Cu}-\mathrm{O}$ stretching } & 474 & \multirow{3}{*}{$\mathrm{Cu}_{2}(\mathrm{OH})_{3} \mathrm{Cl}$-atacamite } & \multirow{3}{*}{ [31] } \\
\hline AAPM & & 473 & & \\
\hline $0.6 \mathrm{~mol} / \mathrm{L} \mathrm{NaCl}$ & & 474 & & \\
\hline PRSF & \multirow{3}{*}{$\mathrm{Cu}-\mathrm{O}$ stretching } & $459,450,444,435$ & \multirow{3}{*}{$\begin{array}{c}\mathrm{Cu}_{2}(\mathrm{OH})_{3} \mathrm{Cl} \text {-botallackite } \\
\text { and atacamite }\end{array}$} & \multirow{3}{*}[30,31]{} \\
\hline AAPM & & 458,444 & & \\
\hline $0.6 \mathrm{~mol} / \mathrm{L} \mathrm{NaCl}$ & & $458,444,434$ & & \\
\hline PRSF & \multirow{3}{*}{$\begin{array}{l}\mathrm{Cu}-\mathrm{O} \text { stretching or internal } \\
\text { vibration of } \mathrm{SO}_{4}^{2-}\end{array}$} & 419 & $\mathrm{Cu}_{2}(\mathrm{OH})_{3} \mathrm{Cl}$-botallackite & \multirow{3}{*}[31,35]{} \\
\hline AAPM & & 420 & $\begin{array}{l}\mathrm{Cu}_{2}(\mathrm{OH})_{3} \mathrm{Cl} \text {-botallackite or } \\
\mathrm{Cu}_{4}(\mathrm{OH})_{6} \mathrm{SO}_{4} \text { - brochantite }\end{array}$ & \\
\hline $0.6 \mathrm{~mol} / \mathrm{L} \mathrm{NaCl}$ & & 419 & $\mathrm{Cu}_{2}(\mathrm{OH})_{3} \mathrm{Cl}$-botallackite & \\
\hline
\end{tabular}

The main detections in all cases are the $\mathrm{Cu}$ (II) hydroxychlorides with the general formula $\mathrm{Cu}_{2}(\mathrm{OH})_{3} \mathrm{Cl}$. In fact, the peaks observed are a better match with synthetic compounds—produced by precipitation experiments [30]—rather than natural minerals $[31,32]$ and correspond to intermediate products between two $\mathrm{Cu}_{2}(\mathrm{OH})_{3} \mathrm{Cl}$ polymorphs, botallackite and atacamite, and their copper chloride precursors. This mixture is poorly crystallized, as indicated by the strong wide band in the range $3360-3310 \mathrm{~cm}^{-1}$. This band consists of a triplet of convoluted peaks, merely resolved. The weak peak at $3522 \mathrm{~cm}^{-1}$ and the strong peak at $419-429 \mathrm{~cm}^{-1}$ are an exact match with the botallackite reference spectrum. Malachite $\left(\mathrm{Cu}_{2}(\mathrm{OH})_{2} \mathrm{CO}_{3}\right)$ was also identified among the corrosion products in all three patinas. In the case of PRSF patina, the higher malachite content is in accordance with the high calcium carbonate concentration dissolved in the soil filtrate. In AAPM patina, the presence of $\mathrm{Cu}_{2}(\mathrm{OH})_{2} \mathrm{CO}_{3}$ originates from the dissolved carbonate salts of the solution, and of course in all corrosive media, dissolved atmospheric $\mathrm{CO}_{2}$ should be considered as a source of carbonates. Some weak characteristic bands (1124 and $482 \mathrm{~cm}^{-1}$ ), related to basic copper sulphates-a closer match to $\mathrm{Cu}_{4}(\mathrm{OH})_{6} \mathrm{SO}_{4}$ (brochantite)-are also observed in the AAPM patina and, to a lesser extent, in the PRSF. The particular peaks in many cases overlap with $\mathrm{Cu}_{2}(\mathrm{OH})_{3} \mathrm{Cl}$ bands and were difficult to distinguish.

Despite the nitrogen detection by EDS elemental analysis locally in the AAPM patina, no matches to basic copper(II) nitrates were found in the AAPM IR spectrum.

The FTIR spectra of some of the weak bands around $1620-1660 \mathrm{~cm}^{-1}$ could be attributed to deformation of $\mathrm{H}_{2} \mathrm{O}$. Broad peaks in this range have been detected in corrosion product samples after anodic polarization in $0.1 \mathrm{~mol} / \mathrm{L} \mathrm{NaCl}$ [33] and in corrosion crusts on buried archaeological bronzes [36] by Robbiola et al. The identification of peaks observed within the range $1570-1020 \mathrm{~cm}^{-1}$ was incomplete, although it could be possible that the overtones of $\mathrm{Sn}-\mathrm{O}-\mathrm{Sn}$ and $\mathrm{Sn}-\mathrm{O}-\mathrm{H}$ vibrations are included. Some individual peaks appearing at 526, 518, 506 and $473,917-922 \mathrm{~cm}^{-1}$, could be attributable to $\mathrm{CuSnO}_{3}$ and to abhurite $\left(\mathrm{Sn}_{21} \mathrm{O}_{6} \mathrm{Cl}_{16}(\mathrm{OH})_{14}\right)$, respectively. According to the Pourbaix themodynamic diagrams and the relevant literature $[33,36,37]$, the presence of mixed $\mathrm{Cu}-\mathrm{Sn}$ oxides was considered unlikely, and the formation of $\mathrm{Sn}$ (II) chloride-containing compounds is not favoured at that particular electrolyte $\mathrm{pH}$ and potential domain. Especially at the end of the polarization sweep (highly anodic potential and strongly alkaline $\mathrm{pH}$ ), compounds such as abhurite - whose formation and stability is favoured at acidic $\mathrm{pH}$-could not be possibly sustained within the patina without further oxidation. In any case, the above-mentioned 
bands were matched to $\mathrm{Cu}_{2}(\mathrm{OH})_{3} \mathrm{Cl}$ compounds. Within the range $400-720 \mathrm{~cm}^{-1}$, characteristic vibrations of $\mathrm{M}-\mathrm{O}$ and $\mathrm{M}-\mathrm{OH}$ type (where $\mathrm{M}: \mathrm{Cu}$ or $\mathrm{Sn}$ ) are observed.

3.2.2. 2nd Experimental Section-Characterization of Electrochemical Patinas in $0.1 \mathrm{~mol} / \mathrm{L} \mathrm{NaCl}$

The anodic polarization curves of $\mathrm{TB}$ and $\mathrm{ZB}$ in $0.1 \mathrm{~mol} / \mathrm{L} \mathrm{NaCl}$ at a slow scan rate are presented in Figure 8. The same basic domains are observed in both curves (Tafel region, intense anodic peak and a stable plateau at high current density levels. A second, weak anodic peak, followed by a dissolution ramp, are observed in brass casting (ZB). The steady state condition, reached above $+400 \mathrm{mV} / \mathrm{SCE}$, leads to the formation of compact corrosion layers. A further investigation is necessary in order to determine whether the mechanism of this stage fulfils the criteria of electrochemical passivation.

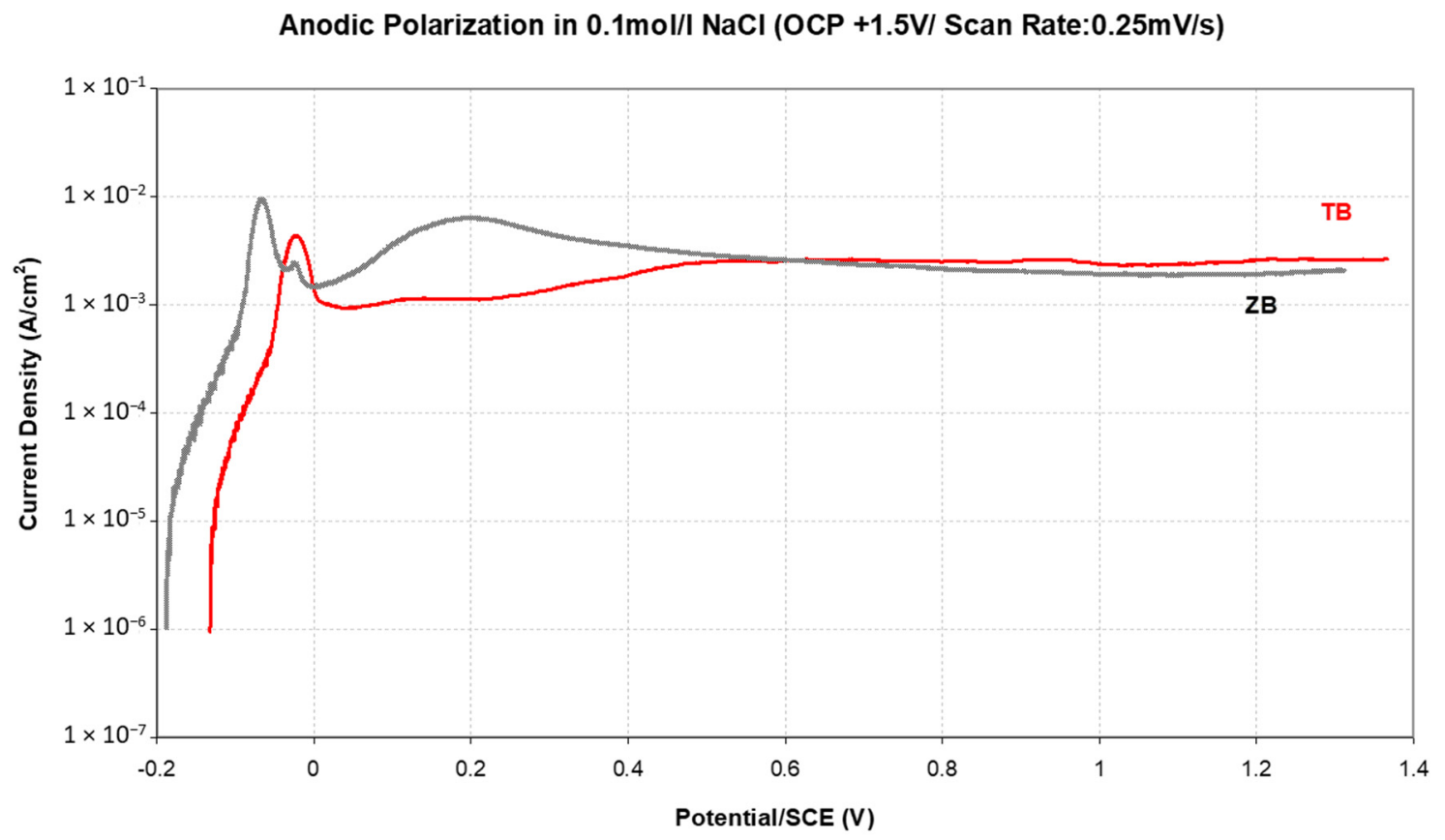

Figure 8. Anodic polarization curves of $\mathrm{TB}$ and $\mathrm{ZB}(\mathrm{OCP}+1.5 \mathrm{~V})$ acquired in $0.1 \mathrm{~mol} / \mathrm{L} \mathrm{NaCl}$ at a slow scan rate of $0.25 \mathrm{mV} / \mathrm{s}$, after $30 \mathrm{~min}$ at OCP conditions. ZB curve was first presented in [29].

The corrosion products expected to be found in the patinas of the $\mathrm{Cu}-\mathrm{Sn}-\mathrm{Pb}$ bronze and $\mathrm{Cu}-\mathrm{Zn}-\mathrm{Sn}-\mathrm{Pb}$ brass, after the sweeps, were copper oxides and chlorides, tin and lead oxides and hydrated tin hydroxy-oxides. Due to the high anodic dissolution rate, the majority of these products are amorphous or nano-crystalline. In our study, very few crystalline compounds were identified by XRD (nantokite and cuprite) and other spectroscopic techniques, such as Raman analyses (not presented in this study), also gave poor results because of the highly impure nature and the distorted stoichiometry (due to outof-equilibrium formation conditions) of these corrosion compounds. Similar observations about poorly crystallized compounds are also reported by case studies dealing with natural and artificial atmospheric corrosion processes-simulating unsheltered urban outdoor conditions-where leaching takes place up to some degree [22]. Following the same methodology as in the previous experimental section, we focused on the elemental mapping by EDS analyses that can provide valuable information about the corrosion products stoichiometry and the dissolution profiles of distinct patina features. The elemental analyses graphs correspond to the average values of small groups of spot or fullframe analyses. The data can be utilized for qualitative assessment of local chemical composition and dealloying trends. More extensive analytical work would be required in order to report accurate quantitative results and support statistical analysis. Some indicative SEM images of the 
internal surface of TB detached patina (Figure 9) and of the TB and ZB alloy (Figure 10) show the typical morphological characteristics of corrosion products epitaxial growth on dendritic structure as a result of patina/alloy interface electrochemical processes.

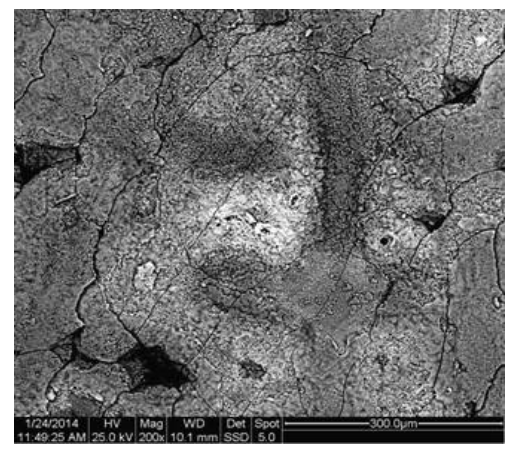

Figure 9. SEM backscattered electron image $(\times 200)$ of TB detached patina (internal surface in contact with metal) after anodic polarization $(\mathrm{OCP}+1.5 \mathrm{~V})$ in $0.1 \mathrm{~mol} / \mathrm{L} \mathrm{NaCl}$ solution.

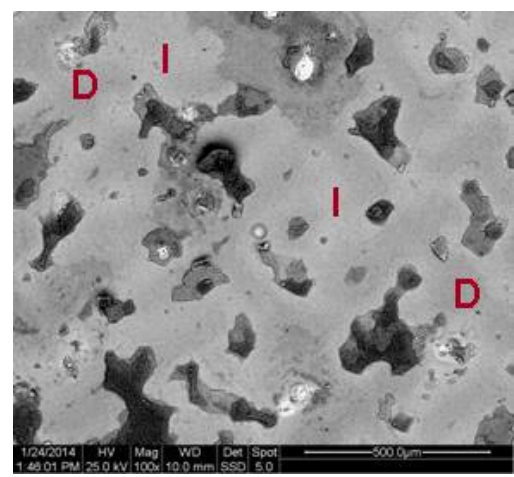

(a)

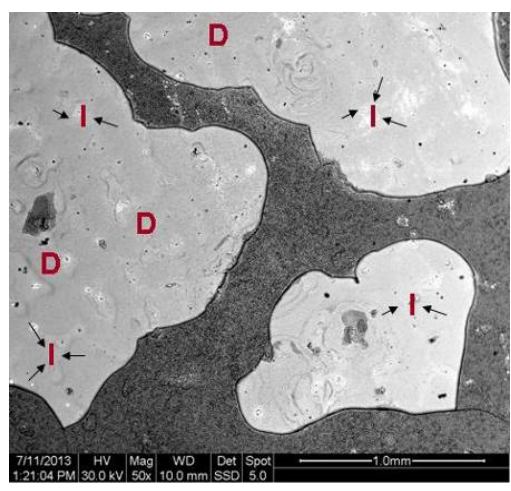

(b)

Figure 10. SEM backscattered electron images of alloy substrates (in contact with patina) after anodic polarization $(\mathrm{OCP}+1.5 \mathrm{~V})$ in $0.1 \mathrm{~mol} / \mathrm{L} \mathrm{NaCl}$ solution: (a) of TB alloy $(\times 100)$; (b) ZB (x50) (D: dendrite, I: interdendritic area).

\section{- $\quad$ TB Casting}

The alloying element concentration profile from the metal matrix towards patina/electrolyte interface testify to the copper depletion (decuprification), which reaches a minimum at the internal patina surface. This tendency is partially reversed towards external patina surfaces (Figure 11). At high anodic potentials, a steady state is reached on both bronze and brass in $\mathrm{NaCl}$ solution (Figure 8), so the formation of a thick and compact film is possible. At the same time, the electrolyte enrichment with dissolved species $\left(\mathrm{CuCl}_{2}{ }^{-}, \mathrm{CuCl}_{3}{ }^{2-}\right.$ etc.) and the local $\mathrm{pH}$ increase at the patina/electrolyte interface allows a partial redeposition of amorphous or nanocrystalline $\mathrm{Cu}$ products. The internal patina surface is characterized by an intense $\mathrm{Sn}$ enrichment. The outer $\mathrm{Sn}$-deficient corrosion layers are considered as a mixture of partially dissolved corrosion layers (formed at the early polarization stages) and precipitated $\mathrm{Cu}$ compounds from the solution. The findings of this study are in good agreement with the general framework of corrosion mechanisms reported in [36], where a very similar electrochemical setup at a slow scan rate was used for the study of anodic dissolution of a homogeneous annealed $\alpha$-bronze $(10 \% \mathrm{wt}$. Sn) in $0.1 \mathrm{~mol} / \mathrm{L} \mathrm{NaCl}$. A further examination of the EDS data allows for the correlation of dendritic segregation structure with the distribution of $\mathrm{Cu}$ and $\mathrm{Sn}$ in TB corrosion stratification. On the base metal in contact with patina, $\mathrm{Cu}$ in dendritic areas is preferentially oxidized. Therefore, 
the evolved corrosion products on the dendritic network are enriched in $\mathrm{Cu}$, and the interdendritic areas are enriched in Sn (Figures 11 and 12).

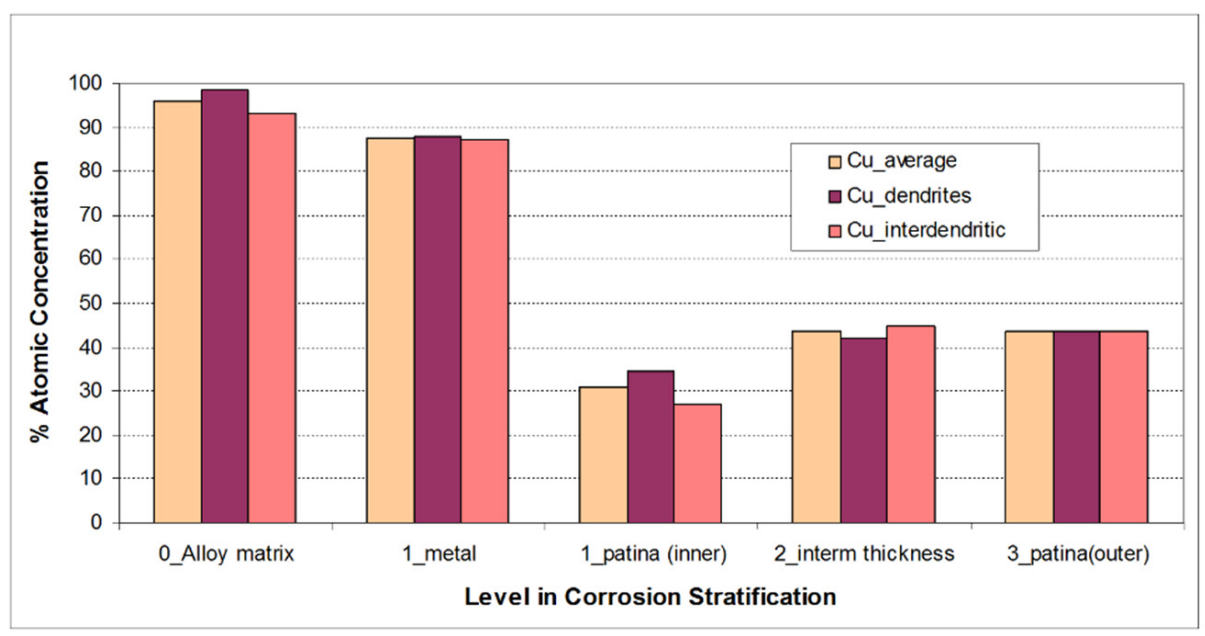

Figure 11. \% Cu atomic concentration profile of the corrosion layer stratification in dendritic and interdendritic areas after TB anodic polarization in $0.1 \mathrm{~mol} / \mathrm{L} \mathrm{NaCl}-$ Based on EDS elemental chemical analyses data (fullframe and spot analyses).

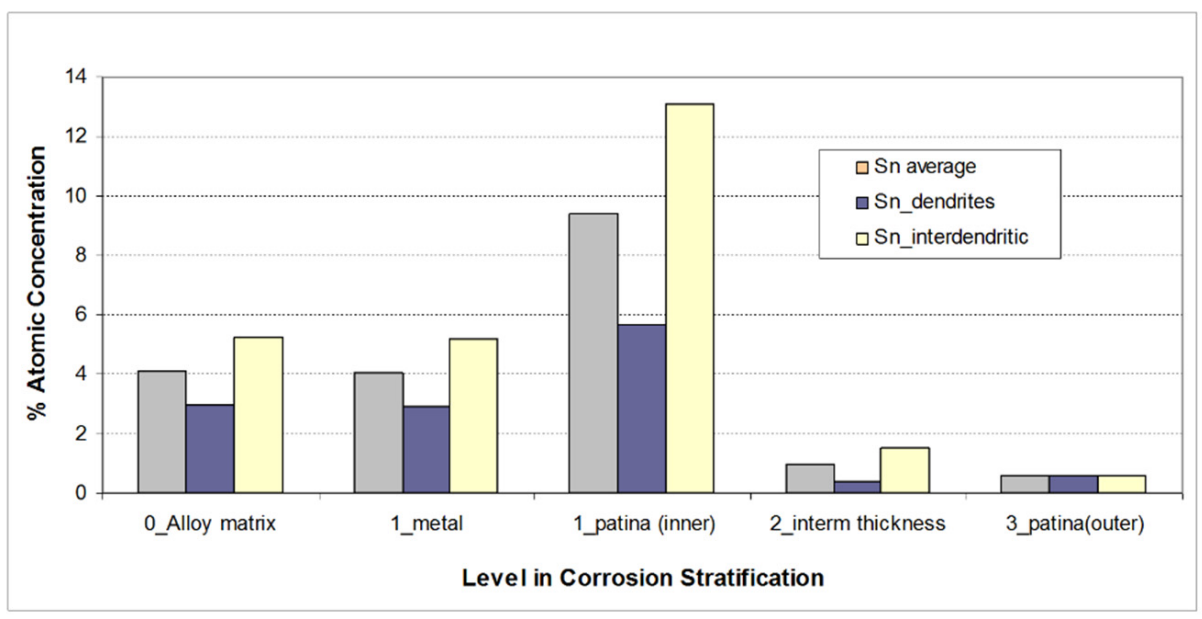

Figure 12. \% Sn atomic concentration profile of the corrosion layer stratification in dendritic and interdendritic areas after TB anodic polarization in $0.1 \mathrm{~mol} / \mathrm{L} \mathrm{NaCl}$-Based on EDS elemental chemical analyses data (fullframe and spot analyses).

At an intermediate depth of corrosion layers, the decuprification process develops faster on products epitaxially grown on dendrites. At the external patina surface, the distribution of both $\mathrm{Cu}$ and $\mathrm{Sn}$ is balanced. Very high $\mathrm{Cl}^{-}$concentration, reaching approximately $41 \%$ at the external and $27 \%$ at the internal patina surface, and low levels (14.5\%) of oxygen species (i.e., oxides, hydroxides and oxyhydroxides) are observed. The chloride diffusion gradient towards the alloy matrix is depicted in Figure 13. 


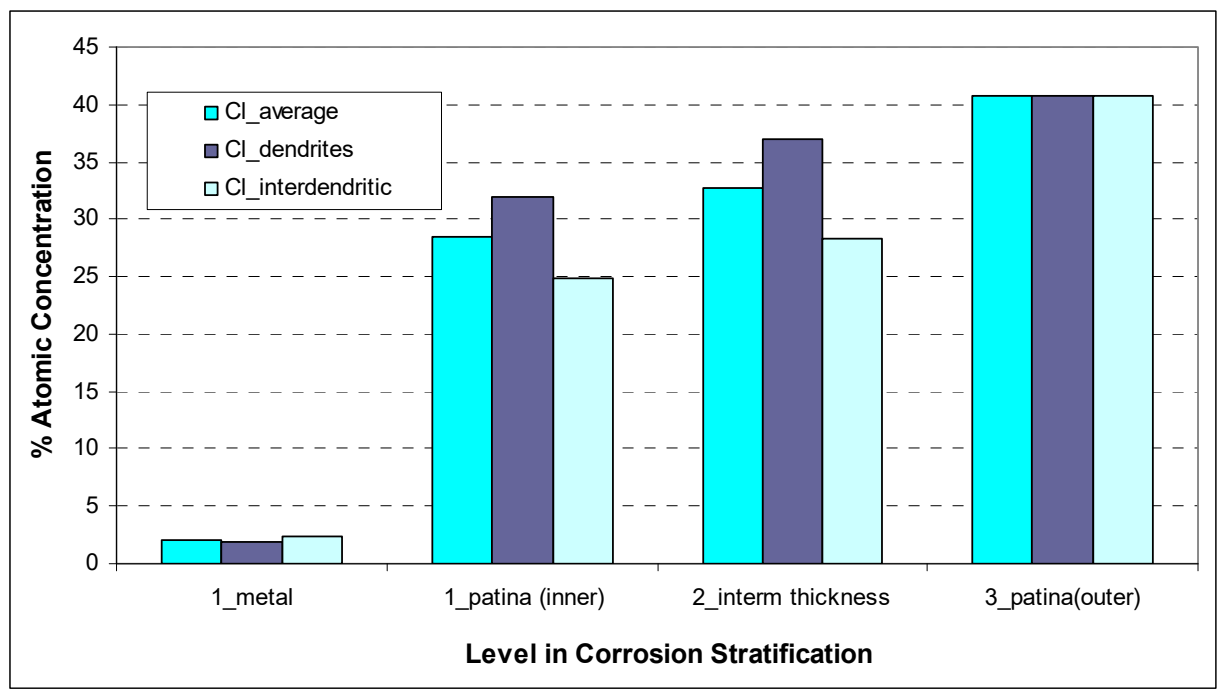

Figure 13. $\% \mathrm{Cl}$ atomic concentration profile of the corrosion layer stratification in dendritic and interdendritic areas after TB anodic polarization in $0.1 \mathrm{~mol} / \mathrm{L} \mathrm{NaCl}$-Based on EDS elemental chemical analyses data (fullframe and spot analyses).

Focusing on the relative distribution of oxygen and chloride species at the internal patina surface, it can be deduced that the corrosion compounds on $\mathrm{Cu}$-enriched are characterized by a higher $\mathrm{Cl} / \mathrm{O}$ atomic ratio-equal to 1.33-(Table 5), while the corrosion compounds on Sn-enriched interdendritic areas are dominated by oxygen species-exhibiting a Cl/O ratio of 0.75 (Table 5).

Table 5. Normalized \% atomic elemental distribution of $\mathrm{O}$ and $\mathrm{Cl}$ (corresponding to $\mathrm{O}^{2-}, \mathrm{Cl}^{-}$anionic species) detected by EDS in the electrochemical patinas of TB and ZB after anodic polarization in $0.1 \mathrm{~mol} / \mathrm{L} \mathrm{NaCl}$. Average values of indicative analyses conducted on both the internal surface in contact with the alloy and the outer surface of the patina (interface with electrolyte).

\begin{tabular}{ccccccc}
\hline \multirow{2}{*}{ Element } & \multicolumn{2}{c}{ TB } & & ZB \\
\cline { 2 - 3 } & \multicolumn{2}{c}{ Interface with Alloy } & $\begin{array}{c}\text { Interface with } \\
\text { Electrolyte }\end{array}$ & $\begin{array}{c}\text { Interface with } \\
\text { Alloy }\end{array}$ & $\begin{array}{c}\text { Interface with } \\
\text { Electrolyte }\end{array}$ \\
\cline { 2 - 3 } & Dendritic Network & Interdendritic Areas & & 26.3 & 38.6 & 13.1 \\
$\mathrm{O}$ & 43.0 & 57.1 & 73.7 & 61.4 & 86.9 \\
$\mathrm{Cl} / \mathrm{O}$ & 57.0 & 42.9 & 2.80 & 1.59 & 6.64 \\
\hline
\end{tabular}

More specifically, local EDS spot analyses confirm that Sn-enriched interdendritic areas contain three times higher oxygen and significantly lower chloride levels $(26 \%)$ compared to the average atomic concentration acquired from low magnification fullframe analyses.

\section{- $\quad$ ZB Casting}

The determination of ZB bulk patina chemical composition and the preliminary characterization of local corrosion features (induced by macro- and micro-segregation) by OM have already been presented in [29]. In this work, a more detailed analysis of the dealloying mechanisms on dendritic microstructure is undertaken, including data re-evaluation where necessary. The dealloying process of the $\mathrm{ZB}$ alloy is initiated by a fast selective dissolution of $\mathrm{Zn}$ (dezincification) towards the patina/electrolyte interface. At the internal patina surface, $\mathrm{Zn}$ is completely eliminated, while at the external patina surface a very low concentration of $\mathrm{Zn}$ has been left undissolved (Figure 14). 


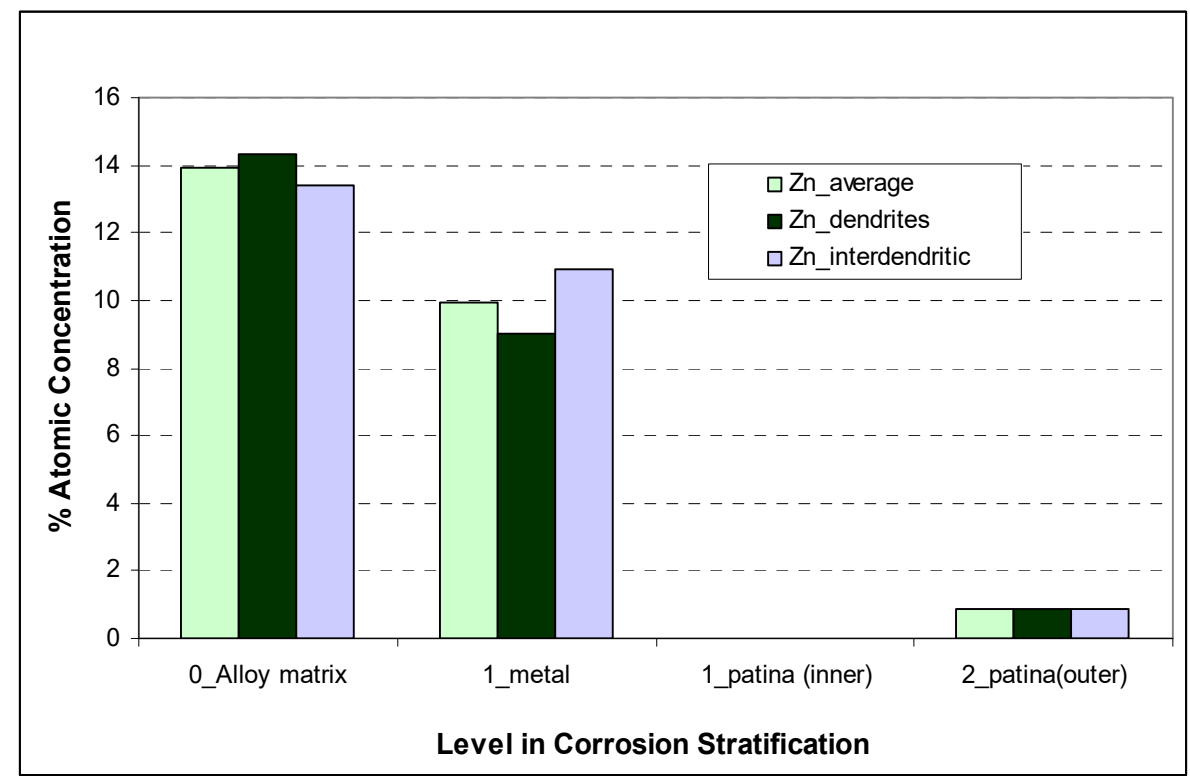

Figure 14. $\% \mathrm{Zn}$ atomic concentration profile of the corrosion layer stratification in dendritic and interdendritic areas after $\mathrm{ZB}$ anodic polarization in $0.1 \mathrm{~mol} / \mathrm{L} \mathrm{NaCl}-\mathrm{Based}$ on EDS elemental chemical analyses data (fullframe and spot analyses).

At the same time, $\mathrm{Cu}$ is also being dissolved at a slower rate. The general decuprification profile of the corrosion stratification reveals a gradual $\mathrm{Cu}$ dissolution from alloy matrix towards internal patina surface, followed by a small increase at the external patina surface (Figure 15). As a consequence, an extensive enrichment in $\mathrm{Sn}$ is observed at the internal patina surface (Figure 16). As with the TB alloy, the increase in $\mathrm{Cu}$ concentration at the external patina surface could be justified by the deceleration of passive layer dissolution at high anodic potentials and the redeposition of dissolved species.

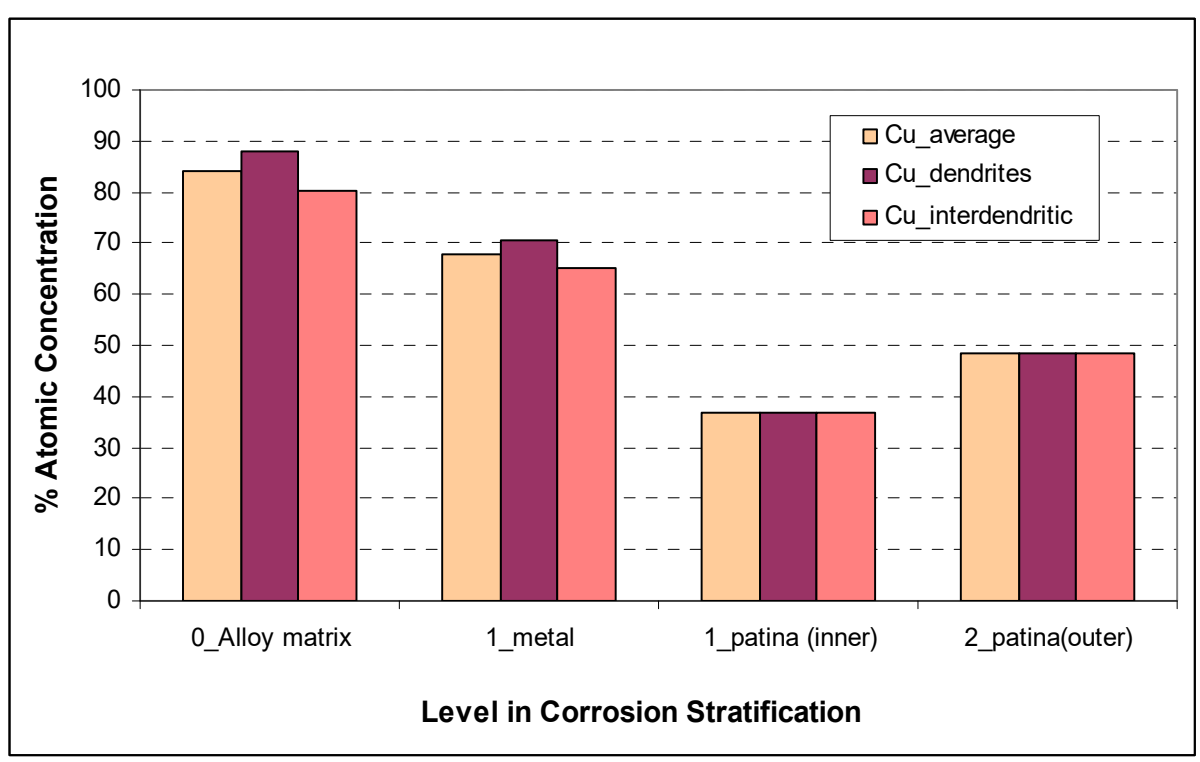

Figure 15. \% $\mathrm{Cu}$ atomic concentration profile of the corrosion layer stratification in dendritic and interdendritic areas after ZB anodic polarization in $0.1 \mathrm{~mol} / \mathrm{L} \mathrm{NaCl}$-Based on EDS elemental chemical analyses data (fullframe and spot analyses). 


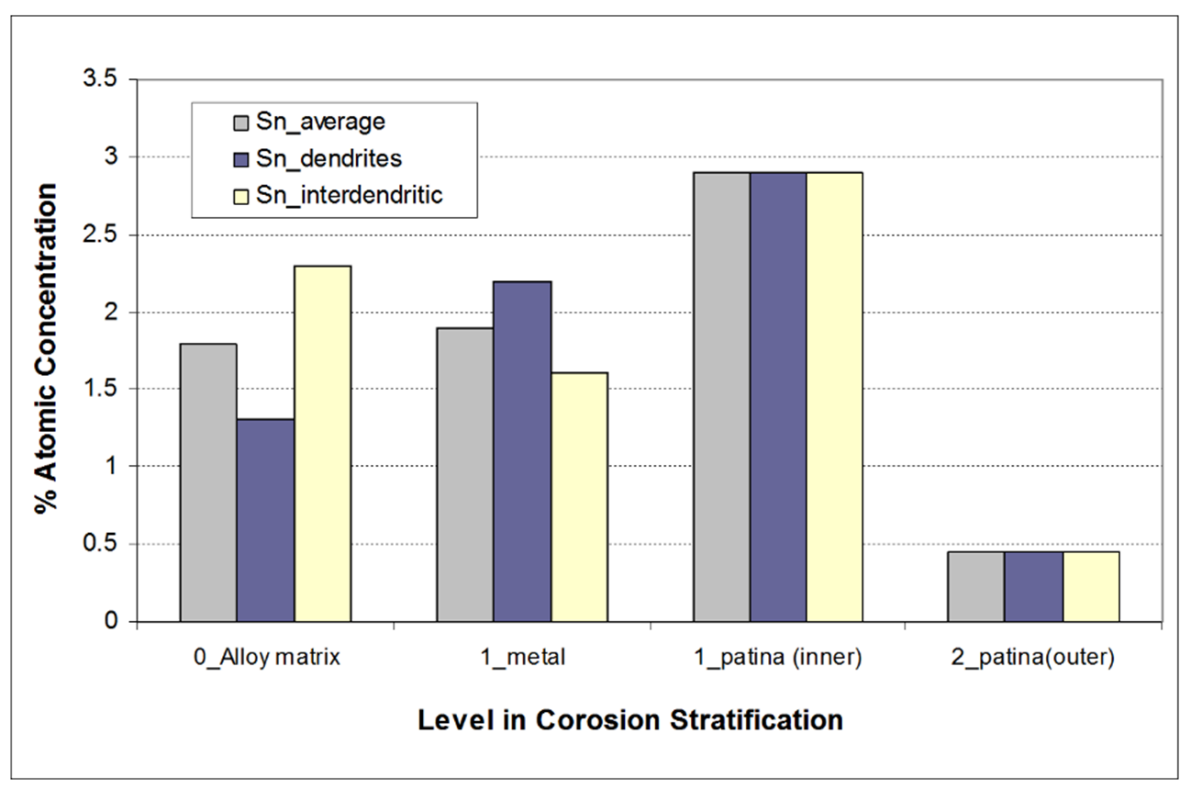

Figure 16. \% Sn atomic concentration profile of the corrosion layer stratification in dendritic and interdendritic areas after $\mathrm{ZB}$ anodic polarization in $0.1 \mathrm{~mol} / \mathrm{L} \mathrm{NaCl}-$ Based on EDS elemental chemical analyses data (fullframe and spot analyses).

At the metal/patina interface, a faster propagation of $\mathrm{Zn}$ dissolution in the dendritic network is observed. Copper, on the other hand, appears to be dissolved at the same rate in both anodic and cathodic sites. The overall $\mathrm{Cu}$ distribution gradient in dendritic and interdendritic areas of the alloy (in contact with patina) remains unchanged. Dezincification and decuprification leave behind $\alpha$-dendrites enriched in Sn compared to the alloy matrix. The internal patina surface appears chemically uniform with no local corrosion patterns, indicating that, at high potential anodic dissolution of $\mathrm{Zn}$ and $\mathrm{Cu}$ through the corrosion film, steady-state conditions are reached.

The relative fractions of oxygen and chloride species at the two sides of the electrochemical patina are given in Table 5. Although the absolute chloride concentration detected on the external surface of the electrochemical TB and ZB patinas was roughly equal $(40.8 \%$ for $\mathrm{TB}$ versus $43.4 \%$ for $\mathrm{ZB}$ ), the $\mathrm{Cl} / \mathrm{O}$ atomic ratio observed in $\mathrm{ZB}(6.64)$ is nearly 2.5 times higher compared to the TB alloy (see Table 5).

\section{Discussion}

In previous publications, the electrochemical behaviour of a ternary $\mathrm{Cu}-\mathrm{Sn}-\mathrm{Pb}(\mathrm{TB})$ and a quaternary $\mathrm{Cu}-\mathrm{Zn}-\mathrm{Sn}-\mathrm{Pb}(\mathrm{ZB})$ alloy in various chloride-containing corrosive media have been reported $[28,29]$. The current research article is dedicated to the evaluation of surface and interface chemical analyses indicative of corrosion topography and stratigraphy after these potentiodynamic tests. This systematic approach enables, at a basic level, the assessment of macro- and especially micro-segregation influence in corrosion mechanisms of archaeometallurgical copper alloy castings.

The chemical characterization of the TB electrochemical patinas in the first experimental section showed that the overall chemical composition of the produced corrosion products mixture in all synthetic corrosive media has many common constituents, as can be deduced by the interpretation of the three FTIR spectra. Apparently, chlorides dominate the corrosion reactions in all media, even in AAPM electrolyte-which is a mixture of corrosive agents, with sulphates $\left(\mathrm{SO}_{4}{ }^{2-}\right)$ being the primary ionic species. Knowing the differences in physicochemical properties of the three chloride-containing media (similar $\mathrm{pH}$ but different ionic conductivities and concentrations of aggressive $\mathrm{Cl}^{-}$and other ionic species) reported in [28], this observation seems contradictory. This fact offers a motivation to evaluate the benefits and limitations of an experimental methodology based on anodic polarization 
tests. In the first experimental section, one type of metal substrate is employed and the exposed surface is uniformly wetted by an electrolyte layer of infinite thickness. The most important kinetic parameters are being controlled (application of the same potential scan rate that imposes equal charge transfer rate). The polarization occurs at roughly the same potential domain. Consequently, it is reasonable that the fundamental electrochemical reactions promoted in these three systems are very similar. However, the corrosion layer stratification and the local topography is unique for each corrosion system (as has been demonstrated by OM and EDS analyses at the alloy-patina interface).

The results of the second experiment section point out that slow potentiodynamic scans proved to be the most suitable approach to study the electrochemical dissolution and leaching processes of bronze in total immersion conditions.

On the subject of experimental methodology design and evaluation, it can be concluded that the electrochemical potentiodynamic tests in soil filtrate and synthetic atmospheric electrolytes cannot reproduce or simulate the natural corrosion processes in these media. The contribution of an electrochemical setup of this type could be in the investigation of (i) the general trends of dealloying mechanisms in the presence of various corrosive species, (ii) the function of local galvanic cells in a well-studied metal topography, and (iii) the redox reactions at the interfaces of metal/corrosion layer/electrolyte.

The most important findings pointed out by the accelerated corrosion through electrochemical potentiodynamic tests in chloride-media $\left(1^{\text {st }}\right.$ and $2^{\text {nd }}$ experimental section $)$ can be summarized as follows:

- Macro-segregation affects the oxidation and dealloying rates at a local scale, according to the geometry of the solidification front. Disc-shaped specimens cut from rod castings exhibit lower $S n$ concentration and smaller grain sizes at the periphery and higher $\mathrm{Sn}$ and larger grains at the specimen centre. The corrosion attack initiates from the $\mathrm{Cu}$-enriched edge and develops towards the centre.

- The differential chemical composition of dendritic microstructure inside the grains is responsible for the action of local micro-galvanic cells where the formation of different corrosion compounds is favoured and variant dealloying rates occur. The establishment of anodic and cathodic sites means that different electrochemical actions occur locally. As a result, the nature of corrosion products is also site-specific.

- In the studied $\alpha$-bronze and $\alpha$-brass corrosion systems, the electrochemical attack initiates from the dendrites which act as anodes, while the interdendritic areas are the cathodic sites. All initial corrosion products are epitaxially grown on the given microstructure and tend to dissolve faster.

- The TB casting - exhibiting a cored dendritic microstructure-has undergone more severe corrosion in the atmospheric pollutants mixture compared to the soil filtrate and the $0.6 \mathrm{~mol} / \mathrm{L} \mathrm{NaCl}$, after anodic polarization $(\mathrm{OCP}+0.6 \mathrm{~V})$ in these electrolytes. The lead phases were selectively attacked by sulphates and nitrates.

- The main corrosion products identified by FTIR in the electrochemical patinas (PRSF, AAPM, $0.6 \mathrm{~mol} / \mathrm{L} \mathrm{NaCl}$ ) of TB casting were basic $\mathrm{Cu}(\mathrm{II})$ hydroxychlorides, basic $\mathrm{Cu}(\mathrm{II})$ hydroxycarbonates and amorphous $\mathrm{Cu}$ and $\mathrm{Sn}$ oxides. In AAPM, some additional bands corresponding to $\mathrm{Cu}(\mathrm{II})$ hydroxysulphate compounds were detected.

- In the first experimental section, it was evidenced that, at moderately anodic potential ranges $(\mathrm{OCP}+0.6 \mathrm{~V})$, the external patina surface still exhibits local corrosion features evolved on the pre-existing dendritic structure chemical inhomogeneity. However, the electrochemical and chemical reactions at the patina/electrolyte interface tend to eliminate or counter-balance the inhomogeneous distribution of alloying elements. Thus, at high anodic potentials $(\mathrm{OCP}+1.5 \mathrm{~V})$, the external surface of TB and ZB electrochemical patinas exhibits uniform chemical composition. This was confirmed by the characterization of patinas, presented in the second experimental section.

- The stratification of electrochemical patinas produced on TB and ZB castings by slow anodic polarization in $0.1 \mathrm{~mol} / \mathrm{L} \mathrm{NaCl}$ reveals a decuprification profile for $\mathrm{TB}$ and synchronous dezincification and decuprification for $\mathrm{ZB}$. 
- The ternary bronze casting (TB) exhibits selective oxidation of the $\mathrm{Cu}$-enriched dendrites and higher decuprification rate in these areas. The corroded interdendritic areas in ternary bronze remain Sn-enriched in respect to the average of the particular surface, and the corrosion compounds exhibit a $\mathrm{Cl} / \mathrm{O}$ atomic ratio of 0.75 , lower than the value calculated for the dendrite network (1.33), which is mainly attacked by chlorides. The $\mathrm{Cl} / \mathrm{O}$ ratio of the external patina surface is determined as 2.80 .

- The quaternary brass casting (ZB) exhibits faster dealloying processes under the same conditions. Selective attack of $\mathrm{Zn}$ initiates from the dendritic network. Dezincification progresses faster at these areas, as indicated by $\mathrm{Zn}$ elimination from the internal corrosion layers, and is further assisted by the higher solubility of the Zn chloride species. Decuprification rate is uniform in all segregated areas. The two processes at the alloy/patina interface leave behind a metal surface, where $\alpha$-dendrites are enriched in Sn compared to the alloy matrix. Both patina interfaces (with metal and electrolyte) exhibit a higher $\mathrm{Cl} / \mathrm{O}$ atomic ratio compared to the $\mathrm{Cu}-\mathrm{Sn}-\mathrm{Pb}$ alloy-the calculated values are 1.59 and 6.64 , respectively.

- On the external patina surfaces of both TB and ZB castings, after slow anodic polarization $(\mathrm{OCP}+1.5 \mathrm{~V})$ in $0.1 \mathrm{~mol} / \mathrm{L} \mathrm{NaCl}$, the uneven elemental distribution is balanced by dissolution redox reactions and redeposition of $\mathrm{Cu}$ complexes.

At this point, it is necessary to clarify the use of the terms 'decuprification' and 'dezincification'. These terms, when used for the interpretation of accelerated corrosion processes (induced by wet electrochemistry potentiodynamic techniques), clearly refer to the selective anodic dissolution of these elements. The morphology of dealloyed surfaces should not be compared with porous metal structures. The latter structures are formed by gradual solid-state diffusion processes that govern natural long-term corrosion phenomena.

A particularly interesting future work would be to extend the investigation of the impact caused by several microstructural features (encountered in archaeometallurgical bronze and brass) in their corrosion mechanisms. It is necessary that data produced by accelerated corrosion protocols will be compared with data from multiple natural corrosion environments for further validation.

Author Contributions: Conceptualization, O.P.; methodology, O.P.; formal analysis, O.P.; resources, O.P.; data curation, O.P.; writing-original draft preparation, O.P.; review and editing, P.V.; supervision, P.V. All authors have read and agreed to the published version of the manuscript.

Funding: This research received no external funding.

Institutional Review Board Statement: Not applicable.

Informed Consent Statement: Not applicable.

Data Availability Statement: The data presented in this study are part of a $\mathrm{PhD}$ research and are available on request from the corresponding author, until the dissertation is made public. Afterwards, the data will be available in a publicly accessible repository.

Conflicts of Interest: The authors declare no conflict of interest.

\section{References}

1. Scott, D.A. Metallography and Microstructure of Ancient and Historic Metals; The Getty Conservation Institute: Singapore, 1991; pp. 5-16, 25-29.

2. Scott, D.A.; Schwab, R. Metallography in Archaeology and Art; Springer: Berlin/Heidelberg, Germany, 2019 ; pp. 5-17. ISBN 978-3-030-11265-3. [CrossRef]

3. Nord, A.G.; Mattsson, E.; Tronner, K. Factors Influencing the Long-term Corrosion of Bronze Artefacts in Soil. Prot. Met. 2005, 41, 339-346. [CrossRef]

4. Robbiola, L.; Blengino, J.-M.; Fiaud, C. Morphology and mechanisms of formation of natural patinas on archaeological Cu-Sn alloys. Corros. Sci. 1998, 40, 2083-2111. [CrossRef]

5. MacLeod, I.D. Identification of Corrosion Products on Non-Ferrous Metal Artifacts Recovered from Shipwrecks. Stud. Conserv. 1991, 36, 222-234.

6. Scott, D.A. Copper and Bronze in Art/Corrosion, Colorants, Conservation; Getty Conservation Institute: Los Angeles, CA, USA, 2002; pp. 43-65. ISBN 0-89236-638-9. 
7. Di Turo, F.; Coletti, F.; De Vito, C. Investigations on alloy-burial environment interaction of archaeological bronze coins. Microchem. J. 2020, 157, 104882. [CrossRef]

8. Ingo, G.M.; Riccucci, C.; Guida, G.; Pascicci, M.; Giuliani, G.; Messina, E.; Fierro, G. Micro-chemical investigation of corrosion products naturally grown on archaeological $\mathrm{Cu}$-based artefacts retrieved from the Mediterranean Sea. Appl. Surf. Sci. 2019, 470, 695-706. [CrossRef]

9. Oudbashi, O. Multianalytical study of corrosion layers in some archaeological copper alloy artefacts. Surf. Interface Anal. 2015, 47, 1133-1147. [CrossRef]

10. Papadopoulou, O.; Vassiliou, P.; Grassini, S.; Angelini, E.; Gouda, V. Soil-induced corrosion of ancient Roman brass-A case study. Mater. Corros. 2016, 67, 160-169. [CrossRef]

11. Quaranta, M.; Catelli, E.; Prati, S.; Sciutto, G.; Mazzeo, R. Chinese archaeological artefacts: Microstructure and corrosion behaviour of high-leaded bronzes. J. Cult. Herit. 2014, 15, 283-291. [CrossRef]

12. Chiavari, C.; Colledan, A.; Frignani, A.; Brunoro, G. Corrosion evaluation of traditional and new bronzes. Mater. Chem. Phys. 2006, 95, 252-259. [CrossRef]

13. Hassairi, H.; Bousselmi, L.; Triki, E. Bronze degradation processes in simulating archaeological soil media. J. Solid State Electrochem. 2010, 14, 393-401. [CrossRef]

14. dos Santos, L.M.M.; Lemos Salta, M.M.; Fonseca, T.E. The electrochemical behaviour of bronze in synthetic seawater. J. Solid State Electrochem. 2007, 11, 259-266. [CrossRef]

15. Lins, A.; Power, T. Corrosion of Bronze Monuments in Urban Sites. In Ancient \& Historic Metals-Conservation and Scientific Research; Proceedings of a Symposium organized by the J. Paul Getty Museum; Scott, D.A., Podany, J., Considine, B.B., Eds.; The Getty Conservation Institute: Singapore, 1991; pp. 119-151. ISBN 0-89236-231-6.

16. Zhou, P.; Ogle, K. The Corrosion of Copper and Copper Alloys. In Encyclopedia of Interfacial Chemistry; Wandelt, K., Ed.; Elsevier: Amsterdam, The Netherlands, 2018; pp. 478-489. [CrossRef]

17. Bozzini, B.; Alemán, B.; Amati, M.; Boniardi, M.; Caramia, V.; Giovannelli, G.; Gregoratti, L.; Kazemian Abyaneh, M. Novel insight into bronze disease gained by synchrotron-based photoelectron spectro-microscopy, in support of electrochemical treatment strategies. Stud. Conserv. 2017, 62, 465-473. [CrossRef]

18. Chang, T.; Maltseva, A.; Volovitch, P.; Wallinder, I.O.; Leygraf, C. A mechanistic study of stratified patina evolution on Sn-bronze in chloride-rich atmospheres. Corros. Sci. 2020, 166, 108477. [CrossRef]

19. Campanella, L.; Colacicchi Alessandri, O.; Ferretti, M.; Plattner, S.H. The effect of tin on dezincification of archaeological copper alloys. Corros. Sci. 2009, 51, 2183-2191. [CrossRef]

20. Brunoro, G.; Laguzzi, G.; Luvidi, L.; Chiavari, C. Corrosion evaluation of artificially aged 6 wt-\% tin bronze. Br. Corros. J. 2001, 36, 227-232. [CrossRef]

21. Chiavari, C.; Rahmouni, K.; Takenouti, H.; Joiret, S.; Vermaut, P.; Robbiola, L. Composition and electrochemical properties of natural patinas of outdoor bronze monuments. Electrochim. Acta 2007, 52, 7760-7769. [CrossRef]

22. Ospitali, F.; Chiavari, C.; Martini, C.; Bernardi, E.; Passarini, F.; Robbiola, L. The characterization of Sn-based corrosion products in ancient bronzes: A Raman approach. J. Raman Spectrosc. 2012, 43, 1596-1603. [CrossRef]

23. Masi, G.; Esvan, J.; Josse, C.; Chiavari, C.; Bernardi, E.; Martini, C.; Bignozzi, M.C.; Gartner, N.; Kosec, T.; Robbiola, L. Characterization of typical patinas simulating bronze corrosion in outdoor conditions. Mater. Chem. Phys. 2017, 200, 308-321. [CrossRef]

24. EFESTUS-Tailored Strategies for the Conservation and Restoration of Archaeological Value Cu-Based Artefacts from Mediterranean Countries, Research Project Funded under FP5 Programme INCO 2, Grant Agreement ID: ICA3-CT-2002-10030, $2003-2005$. Available online: https:/ / cordis.europa.eu/project/id/ICA3-CT-2002-10030 (accessed on 20 April 2021).

25. Casaletto, M.P.; De Caro, T.; Ingo, G.M.; Riccucci, C. Production of reference "ancient" Cu-based alloys and their accelerated degradation methods. Appl. Phys. A 2006, 83, 617-622. [CrossRef]

26. Vander Voort, G.F. Color Etching. In ASM Metals Handbook; ASM International: Almere, The Netherlands, 2020; Volume 9, pp. 229-233.

27. Eleftheriadis, K.; Balis, D.; Ziomas, I.C.; Colbeck, I.; Manalis, N. Atmospheric aerosol and gaseous species in Athens, Greece. Atmos. Environ. 1998, 32, 2183-2191. [CrossRef]

28. Papadopoulou, O.; Vassiliou, P. Electrochemical behaviour of ancient-like ternary Cu alloys in aqueous chloride media. In Proceedings of the Joint European Corrosion Congress 2017, EUROCORR 2017 and 20th International Corrosion Congress and Process Safety Congress 2017, Prague, Czech Republic, 3-7 September 2017.

29. Papadopoulou, O.; Delagrammatikas, M.; Vassiliou, P.; Grassini, S.; Angelini, E.; Gouda, V. Surface and interface investigation of electrochemically induced corrosion on a quaternary bronze. Surf. Interface Anal. 2014, 46, 771-775. [CrossRef]

30. Stoilova, D.; Vassileva, V. Infrared spectroscopic study of solids in the $\mathrm{Cu}_{2}(\mathrm{OH})_{3} \mathrm{Cl}($ paratacamite $)-\mathrm{Zn}_{5}(\mathrm{OH})_{8} \mathrm{Cl}_{2} \cdot \mathrm{H}_{2} \mathrm{O}(\mathrm{si}-$ monkolleite) series. Comptes Rendus Académie Bulg. Sci. 2002, 55, 51-54.

31. Braithwaite, R.S.; Mereiter, K.; Paar, W.H.; Clark, A.M. Herbertsmithite, $\mathrm{Cu}_{3} \mathrm{Zn}(\mathrm{OH})_{6} \mathrm{Cl}_{2}$, a new species, and the definition of paratacamite. Mineral. Mag. 2004, 68, 527-539. [CrossRef]

32. Martens, W.; Frost, R.L.; Williams, P.A. Raman and infrared spectroscopic study of the basic copper chloride minerals-implications for the study of the copper and brass corrosion and "bronze disease". Neues Jahrb. Mineral. Abh. 2003, 178, 197-215. [CrossRef] 
33. Robbiola, L.; Tran, T.T.M.; Dubot, P.; Majerus, O.; Rahmouni, K. Characterisation of anodic layers on Cu-10Sn bronze (RDE) in aerated $\mathrm{NaCl}$ solution. Corros. Sci. 2008, 50, 2205-2215. [CrossRef]

34. Di Carlo, G.; Giuliania, C.; Riccucci, C.; Pascucci, M.; Messina, E.; Fierro, G.; Lavorgna, M.; Ingo, G.M. Artificial patina formation onto copper-based alloys: Chloride and sulphate induced corrosion processes. Appl. Surf. Sci. 2017, 421, 120-127. [CrossRef]

35. Malvault, J.Y.; Lopitaux, J.; Delahaye, D.; Lenglet, M. Cathodic reduction and infrared reflectance spectroscopy of basic copper(II) salts on copper substrate. J. Appl. Electrochem. 1995, 25, 841-845. [CrossRef]

36. Robbiola, L.; Hurtel, L.-P. Standard Nature of the Passive Layers of Buried Archaeological Bronze-The Example of Two Roman Half-length Portraits. In Proceedings of the METAL 95: International Conference on Metals Conservation, Semur-en-Auxois, France, 25-28 September 1995; pp. 109-117. Available online: https://hal.archives-ouvertes.fr/hal-00975718 (accessed on 1 March 2021).

37. Jouen, S.; Lefez, B.; Sougrati, T.; Hannoyer, B. Fourier transform infrared spectroscopic study of abhurite $\mathrm{Sn}_{21} \mathrm{O}_{6} \mathrm{Cl}_{16}(\mathrm{OH})_{14}$. Mater. Chem. Phys. 2007, 105, 189-193. [CrossRef] 